\title{
O Lobby da Indústria no Congresso Nacional: Empresariado e Política no Brasil Contemporâneo*
}

Wagner Pralon Mancuso

m maio de 1995, industriais de todo o país reuniram-se com de¿ putados federais e senadores filiados a partidos políticos de diversas tendências ideológicas na sede da Confederação Nacional da Indústria - CNI, em Brasília, para participar do seminário Custo Brasil - Diálogo com o Congresso Nacional. Desde então, e até hoje, reduzir o custo Brasil tornou-se a expressão que resume a principal demanda dirigida pelo empresariado industrial ao poder público para favorecer o crescimento econômico do país, em geral, e o fortalecimento da indústria, em particular.

Custo Brasil é uma expressão utilizada não apenas por empresários, mas também por políticos, por acadêmicos, pela imprensa e pelo público em geral, para designar fatores que prejudicam a competitividade das empresas do país diante de empresas situadas em outros países. Na concepção utilizada neste artigo, seis fatores compõem o custo Brasil: excesso e má qualidade da regulação da atividade econômica; legislação trabalhista inadequada; sistema tributário que onera a pro-

\footnotetext{
* A bolsa de estudos concedida pela Fundação de Amparo à Pesquisa do Estado de São Paulo - FAPESP (processo $\mathrm{n}^{\circ}$ 00/02833-0) viabilizou a pesquisa que deu origem a este artigo. Agradeço os comentários dos professores Maria Hermínia Tavares de Almeida, Fernando de Magalhães Papaterra Limongi e Leandro Piquet Carneiro. Agradeço também os comentários e as sugestões dos pareceristas anônimos de Dados.
}

DADOS - Revista de Ciências Sociais, Rio de Janeiro, Vol. 47, n3, 2004, pp. 505 a 547. 
dução; elevado custo de financiamento da atividade produtiva; infra-estrutura material insuficiente; infra-estrutura social deficiente (CNI, 1996a; 1998a).

Como explicar o fato de a indústria no Brasil, em meados da década de 90 , ter sido capaz de superar os problemas de ação coletiva típicos de um grupo formado por muitos atores heterogêneos e de adotar uma agenda comum formada por temas que superam as clivagens que dividem as empresas em função da competição pelo mercado, ou do seu porte, ou do ramo de atividade em que atuam? Como explicar, enfim, que a redução do custo Brasil se tenha constituído na síntese da agenda política do empresariado industrial?

Na primeira seção do artigo, argumento que a emergência da pauta de interesses comuns decorreu de dois fatores: em primeiro lugar, a elevação da competitividade ao patamar de objetivo prioritário das empresas industriais; em segundo, o trabalho conjunto de organizações do setor industrial para definir o conteúdo do custo Brasil e pugnar por sua redução.

Na segunda, mostro como o setor industrial efetivamente atua ao longo do processo de produção legislativa federal referente à questão do custo Brasil. A atividade política do empresariado industrial é classificada em diferentes modalidades de ação. Além disso, discuto o efeito das instituições que regem o processo de produção legislativa sobre as atividades de articulação de interesses desempenhadas pela indústria.

Na terceira seção, apresento o método adotado para mensurar o grau de sucesso e insucesso obtido pela indústria em processos de produção legislativa relativos ao custo Brasil.

Na quarta, apresento os resultados obtidos pela aplicação do método definido na seção anterior.

As evidências resumidas na conclusão sugerem que o empresariado industrial brasileiro geralmente é mais bem-sucedido em suas incursões no campo da política do que parte da literatura faz supor. 


\section{O CUSTO BRASIL ENTRA NA PAUTA}

\section{Competitividade como Prioridade da Indústria no Brasil}

A abertura comercial é um componente central do conjunto de medidas que foram adotadas para reorientar o modelo econômico do país em uma direção mais liberal. A tendência de queda nas barreiras tarifárias e não tarifárias às importações foi predominante ao longo dos anos 90, feitas as devidas ressalvas aos momentos em que a tendência geral foi contraposta por movimentos no sentido contrário, ou seja, por aumentos de tarifas em benefício de setores industriais específi$\cos$. Na verdade, as primeiras decisões relevantes no que tange à abertura comercial remontam à metade final do governo Sarney. De fato, uma revisão no quadro de tarifas do imposto de importação realizada em 1988 reduziu a tarifa média incidente sobre produtos industriais de $55,6 \%$ para $37,5 \%$, o que representa uma queda global de $32,5 \%$ (Suzigan e Villela, 1997:215). O grande impulso para a abertura comercial aconteceu, no entanto, sob o governo Collor. Em 1990, no primeiro ano de seu governo, Collor extinguiu a maior parte das barreiras não tarifárias às importações, não apenas abolindo uma lista composta por centenas de produtos cuja importação era proibida, mas também pondo um fim à grande maioria dos regimes especiais de importação (exceção feita, por exemplo, aos casos da Zona Franca de Manaus e do setor de informática $)^{1}$. Ainda naquele ano, Collor promoveu uma série de reduções nas tarifas de importação de produtos industrializados tais como têxteis; máquinas e insumos agrícolas; bens de capital não produzidos no país; produtos químicos e petroquímicos; cimento; alumínio e aço. Logo no início do ano seguinte, o governo divulgou um cronograma de reduções graduais de tarifas a ser cumprido em quatro etapas anuais, de 1991 a 1994. O cronograma foi cumprido e, mais do que isso, as duas últimas etapas foram antecipadas, de modo que durante a administração Collor foram vencidas três etapas do cronograma, e a última foi concluída no governo de Itamar Franco, que sucedeu Collor após sua renúncia (Tabela 1).

Ao longo do primeiro semestre de 1994, sob o governo Franco, quando estavam sendo lançadas as bases do Plano Real, foi deflagrada uma nova série de reduções das tarifas de dezenas de produtos industrializados. As reduções continuaram por todo o segundo semestre, após a adoção da nova moeda, concentrando-se, todavia, em agosto e setembro, quando o governo emitiu portarias que antecipavam a Ta- 
Tabela 1

Cronograma (Previsto e Efetivado) de Redução das Tarifas de Importação sob o Governo Collor

\begin{tabular}{l|c|c|c|c|c}
\hline & $\begin{array}{r}\text { Situação } \\
\text { Original }\end{array}$ & $\mathbf{1}^{\underline{a}}$ Etapa & 2 $^{\text {a }}$ Etapa & $3^{\underline{a}}$ Etapa & $\mathbf{4}^{\text {a }}$ Etapa \\
\hline Cronograma previsto & - & $15 / 2 / 1991$ & $1 / 1 / 1992$ & $1 / 1 / 1993$ & $1 / 1 / 1994$ \\
Cronograma efetivado & - & $15 / 2 / 1991$ & $1 / 1 / 1992$ & $1 / 10 / 1992$ & $1 / 7 / 1993$ \\
Tarifa média (\%) & 32,2 & 25,3 & 21,2 & 17,1 & 14,3 \\
Tarifa modal (\%) & 40,0 & 20,0 & 20,0 & 20,0 & 20,0 \\
Desvio padrão (\%) & 19,6 & 17,4 & 14,2 & 10,7 & 7,9 \\
\hline
\end{tabular}

Fonte: Suzigan e Villela (1997:90).

rifa Externa Comum - TEC do Mercosul. A redução de tarifas foi amplamente utilizada como uma medida para conter o aumento de preços, que poderia colocar em risco o sucesso do programa de estabilização. Na segunda metade da década de 1990, sob o governo Cardoso, foram mantidas as tarifas reduzidas para a maioria dos produtos industrializados, mas já a partir de 1995 alguns setores importantes da indústria nacional obtiveram tarifas mais elevadas para os produtos concorrentes oriundos do mercado internacional, por meio da inclusão de seus produtos na Lista Nacional de Exceções à TEC. Dentre esses setores se destacam os de equipamentos de transporte, aparelhos eletrodomésticos, produtos eletrônicos de consumo e alguns segmentos da indústria têxtil e de vestuário (Hay, 1997; Suzigan e Villela, 1997).

A abertura comercial aumentou a entrada de produtos importados no mercado brasileiro, que recebeu forte impulso adicional com a sobrevalorização do real perante o dólar, prevalecente desde a adoção da nova moeda, em meados de 1994, até $1998^{2}$. O aumento das importações expôs a indústria a um grau inédito de competição internacional (Suzigan e Villela, 1996; Moreira e Correa, 1997; Rossi Júnior e Ferreira, 1999; Siqueira, 2000; Haguenauer et alii, 2001). O coeficiente de importação para o setor industrial como um todo cresceu muito ao longo da década de 1990, evoluindo de 5,9\% em 1990 para 19,3\% em 1998, um aumento de aproximadamente 227\% (Moreira, 1999).

As empresas do setor industrial não puderam permanecer alheias ao novo ambiente de maior concorrência da década de 1990. Por um lado, a década foi marcada pelo aumento das operações de fusão e de 
aquisição, lideradas por empresários nacionais e estrangeiros que compraram empresas menos aptas para lidar com o novo contexto (Bonelli, 2000; Miranda, 2001). Por outro lado, muitas empresas - tanto as que foram submetidas a operações de fusão e aquisição, quanto as que sobreviveram - passaram por um processo intenso de ajuste, caracterizado pela redução de pessoal empregado; redução das hierarquias no interior da firma; introdução de processos produtivos mais compactos; concentração das atividades das empresas nas áreas de maior competência, com a conseqüente redução das operações realizadas diretamente pelas empresas (terceirização); implantação de programas de melhoria da qualidade dos produtos; e por investimentos na modernização das instalações existentes, favorecidos pelo barateamento dos bens de capital devido à abertura aos importados e, a partir de 1994, à valorização do real (Bonelli e Gonçalves, 1998; Bielchowsky, 1999; Siqueira, 2000; Castro, 2001; Coutinho e Ferraz, 2002).

O processo de ajuste empreendido por parcela significativa da indústria brasileira em face do ambiente de menor proteção é identificado por vários autores (Lyra, 1996; Sabóia e Carvalho, 1997; Bonelli, 2001) como o elo que liga a abertura comercial ao grandioso crescimento da produtividade na década de 1990, fartamente documentado pela literatura (Hay, 1997; Bonelli, 1998; 2002; Bielchowsky, 1999; Rossi Júnior e Ferreira, 1999; Moreira, 1999). A taxa de crescimento da produtividade do trabalho na indústria na década de 1990 foi superior não apenas à taxa média do período 1949-2000 como um todo, mas também à taxa alcançada em períodos de avanço marcante da industrialização no país, como as décadas de 1950, 1960 e 1970 (Tabela 2).

Tabela 2

Crescimento da Produtividade na Indústria

\begin{tabular}{c|c}
\hline Período & \% por ano \\
\hline $1949-1959$ & 5,84 \\
$1959-1970$ & 3,31 \\
$1970-1975$ & 2,80 \\
$1975-1980$ & 1,94 \\
$1980-1985$ & $-2,83$ \\
$1985-1990$ & $-0,68$ \\
$1990-1995$ & 7,19 \\
$1995-2000$ & 8,31 \\
$\mathbf{1 9 4 9 - 2 0 0 0}$ & 3,45 \\
\hline
\end{tabular}

Fonte: Bonelli (2002:5). 
A contrapartida negativa do crescimento inédito da produtividade da indústria brasileira na década de 1990 foi o aumento das demissões no setor, fenômeno que a literatura associa, parcialmente, ao ajuste empreendido pelas firmas em resposta ao maior grau de abertura da economia (Arbache et alii, 2001; Bonelli, 2001), mas que não pode ser atribuído exclusivamente àquele fator, sendo necessário levar também em conta os efeitos negativos exercidos sobre o emprego industrial pelo baixo crescimento econômico no período (Bonelli e Gonçalves, 1998; IEDI, 2000), freqüentemente associado às taxas de juros altas, sempre mantidas muito acima das principais taxas de juros do mercado internacional e elevadas ainda mais durante os períodos das crises do México em 1995, da Ásia em 1997, da Rússia em 1998 e da Argentina em 2002. Os juros altos encareceram o crédito e afetaram negativamente o nível de investimento na indústria (Pinheiro et alii, 1999; Siqueira, 2000).

Em síntese, importa mostrar que a concorrência no setor industrial brasileiro se tornou mais acirrada ao longo da década de 1990. Expostas ao novo cenário, várias empresas não puderam subsistir e sucumbiram às fusões e aquisições. Muitas empresas, por outro lado, responderam com estratégias de ajuste e com elevação da produtividade. A competitividade tornou-se, portanto, a palavra-chave para a sobrevivência nesse ambiente de menor proteção. As empresas e as associações empresariais que pugnam pela redução do custo Brasil estão convencidas de que esta medida teria repercussão positiva sobre a competitividade industrial.

\section{A CNI, a RedIndústria e as Agendas Legislativas da Indústria}

O acirramento da concorrência e o desafio da competitividade são condições necessárias, mas não suficientes para a formação de uma agenda política comum centrada na redução do custo Brasil. Outro elemento que viabilizou a definição da agenda foi o trabalho coletivo das organizações que representam os interesses da indústria, coordenado pela CNI, entidade de cúpula do setor.

Com efeito, a CNI divulga anualmente, desde 1996, a Agenda Legislativa da Indústria, publicação que exprime a posição do setor diante de proposições legislativas que tramitam no Congresso Nacional e cuja aprovação, reforma ou rejeição teria o potencial de reduzir o custo Brasil ou impedir o seu aumento. A preparação das agendas legislati- 
vas é coordenada pela CNI e realizada pela RedIndústria, rede de organizações empresariais que abrange, além da própria CNI, as federações da indústria de todos os estados brasileiros e do Distrito Federal, assim como dezenas de associações setoriais de abrangência nacional.

A constatação de que os industriais desempenham um vultoso trabalho conjunto para identificar os projetos de maior impacto sobre o custo Brasil, definir uma posição comum e promover esta posição durante o processo legislativo contraria a tese da debilidade política da indústria no Brasil, defendida com vigor em numerosos trabalhos recentes e que tem atingido o status de sabedoria convencional sobre o assunto na literatura internacional (Schneider, 1997a; 1997b; 1998; 2002; Weyland, 1998a; 1998b; 2001; Kingstone, 2001; Power e Doctor, 2002). Os parágrafos seguintes resumem a essência da tese.

Em geral, a debilidade que esses trabalhos apontam pode ser entendida como a incapacidade do empresariado industrial em atingir um consenso em torno de objetivos comuns, assim como de mobilizar um apoio decidido para a realização desses objetivos. Na situação particular em que o país se encontra, marcada pela mudança do modelo de desenvolvimento econômico, a debilidade manifesta-se na incapacidade de definir e promover as decisões políticas necessárias para incrementar sua competitividade; em outras palavras, na incapacidade de oferecer um apoio eficaz para a redução do custo Brasil. A realização das reformas associadas à redução do custo Brasil é percebida por aqueles autores como uma condição indispensável para que a iniciativa privada assuma a função de protagonista que lhe é reservada pelo novo modelo de desenvolvimento. Por sua vez, a debilidade política do empresariado industrial é concebida como o fator que explica a incompetência do setor para viabilizar o desempenho de sua parte naquela função ${ }^{3}$.

Para os expoentes da tese da debilidade da indústria, a causa fundamental da debilidade é a configuração do sistema de representação de interesses do setor, caracterizado simultaneamente pela fragmentação excessiva e pela falta de representatividade das associações de maior abrangência.

Dividido por uma miríade de organizações - tanto da estrutura corporativa (sindicatos, federações e confederações), quanto da estrutu- 
ra extracorporativa (associações setoriais) -, o empresariado industrial mostra-se incapaz de construir um acordo em torno de um programa voltado para o aumento da competitividade sistêmica, e de atuar unido pelo sucesso desse programa.

Fragmentado em numerosas "coalizões distributivas" (Olson, 1982), o empresariado industrial empenha os recursos políticos à sua disposição em rent-seeking (Tullock, 1993), ou seja, para arrancar do poder público toda a sorte de vantagens particulares, tais como tratamento tributário favorecido, crédito subsidiado com taxas de juros diferenciadas, proteção especial contra a competição, entre outras. Os benefícios criados artificialmente por decisões casuísticas como essas são apropriados com exclusividade pelas empresas e segmentos industriais privilegiados. A intenção de agir de forma tão estreita é reforçada pela constatação de que o custo da ação política necessária para alcançar os enormes benefícios exclusivos é sempre menor do que o custo da mobilização da indústria como um todo. Em sua busca incessante por privilégios, as organizações empresariais setoriais não demonstram nenhum interesse pelo impacto que as medidas defendidas porventura irão exercer sobre o público em geral. Do mesmo modo, as associações atomizadas não dispensam nenhuma atenção para as conseqüências de suas demandas sobre as finanças públicas e a estabilidade da economia do país.

A tendência centrífuga poderia ser contrabalançada pela atuação das entidades empresariais de maior abrangência, como a CNI e a Federação das Indústrias do Estado de São Paulo - FIESP. Isto não ocorre, no entanto, porque essas entidades são pouco representativas. Tanto a FIESP - que representa os industriais do estado mais industrializado do país - quanto a CNI - que representa toda a indústria em âmbito nacional - são associações que pertencem ao sistema corporativista. Graças à legislação corporativista, associações de grau inferior de diferentes níveis de relevância econômica têm importância equivalente na vida política interna das associações de grau superior como a FIESP e a CNI. Em decisões internas da FIESP, sindicatos patronais que representam regiões e ramos industriais de relevância marginal dentro da indústria paulista possuem peso equiparável ao dos sindicatos que representam áreas e ramos industriais mais significativos.

No caso da CNI, as federações dos estados menos industrializados têm peso semelhante ao das federações dos estados mais desenvolvi- 
dos. Ou seja, as práticas corporativistas que prevalecem em entidades abrangentes como a FIESP e a CNI distorcem a importância relativa dos diversos segmentos industriais, exagerando a importância dos segmentos menos relevantes e atenuando a importância daqueles mais expressivos. A distorção introduzida pelas práticas corporativistas exerce um efeito direto e negativo sobre a representatividade das associações mais abrangentes; afinal de contas, justamente os segmentos industriais de maior poderio econômico não se reconhecem plenamente nestas entidades. A distorção é especialmente perceptível no momento de seleção dos líderes das associações, em que a escolha freqüentemente recai sobre empresários de menor porte, provenientes de regiões de menor grau de industrialização, em vez de incidir sobre os principais industriais das regiões mais industrializadas do país. Como as associações de maior abrangência não representam com fidelidade o conjunto da indústria, elas não têm condições de engendrar uma ação coletiva conseqüente em favor dos objetivos que unificam o setor - por exemplo, a redução do custo Brasil. Assim, a falta de representatividade dessas entidades também responde pela debilidade política da indústria no país.

Os expoentes da tese da debilidade política do empresariado industrial não vêem nenhuma saída para o problema de ação coletiva do setor dentro do aparato organizacional atualmente existente. Os autores são unânimes em afirmar que a alternativa mais promissora - tanto para o setor, quanto para o país - é a criação de uma inédita associação empresarial de cúpula, que coloque a indústria lado a lado com todos os outros setores da economia - agricultura, comércio, finanças e demais serviços. A nova associação multissetorial é vista pelos autores como o fórum mais adequado para a formação de um consenso geral em torno de políticas públicas capazes de tornar a economia nacional mais eficiente. A associação ainda serviria, ao mesmo tempo, para potencializar o alcance da ação política do empresariado e para contrapesar a busca de interesses setoriais exclusivos - problema que não é uma particularidade da indústria, pois também está presente em todos os outros campos de atividade econômica.

A Figura 1 resume o argumento dos proponentes da tese da debilidade da indústria no Brasil.

Não cabe reparo algum à constatação dos autores sobre a presença generalizada do comportamento de rent-seeking. De fato, não escapa a 
Figura 1

Tese da Debilidade Política do Empresariado Industrial no Brasil

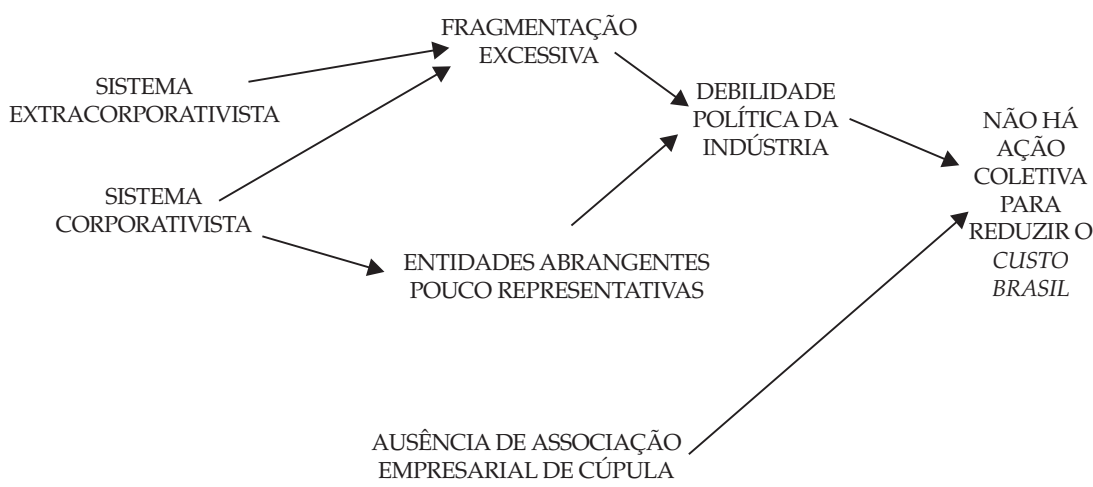

nenhum observador da cena política brasileira que várias empresas e associações empresariais do segmento industrial têm sabido explorar as oportunidades oferecidas pelo sistema político para extrair vantagens particulares e que os privilégios assim alcançados trazem conseqüências negativas para as finanças públicas e para o resto da sociedade.

No entanto, os expoentes da tese da debilidade política da indústria parecem ainda não ter notado que o comportamento de rent-seeking, embora amplamente disseminado, não é a única forma de atuação política da indústria. A ação política do setor é mais complexa e variada do que a tese faz supor. A lógica exclusivista do rent-seeking convive com outras lógicas de ação política. Não obstante a enorme fragmentação do empresariado industrial, e o impulso centrífugo decorrente desta fragmentação, pelo menos desde meados da década de 1990 a indústria vem realizando um grande trabalho coletivo para definir e defender uma posição comum em relação a propostas legislativas que tramitam no Poder Legislativo federal e cuja aprovação, reforma ou rejeição pode contribuir para a solução de problemas que afetam negativamente a competitividade de todo o segmento.

Essa mobilização é o resultado da confluência entre um processo de natureza econômica, que tornou a competitividade em meta prioritária, e a iniciativa de um ator político - a CNI - que se dispôs a assumir o custo de organizar a ação coletiva do setor e que é capaz de assumir esse custo, seja por ocupar uma posição propícia como entidade de 
cúpula do segmento, seja por contar com recursos financeiros suficientes, garantidos por seu quinhão na contribuição sindical compulsória paga pelas empresas 4 .

\section{A INDÚSTRIA ARTICULA SEUS INTERESSES}

A atividade econômica desenvolvida pelas indústrias está exposta ao impacto de inúmeras decisões tomadas cotidianamente por indivíduos que ocupam posições de autoridade nos diversos Poderes - Executivo, Legislativo e Judiciário - de âmbito municipal, estadual e federal. A percepção de que as decisões do poder público têm o poder de interferir sobre as atividades das suas empresas leva muitos empresários - diretamente ou por meio de representantes - a desenvolver atividades de articulação de interesses.

Neste artigo, focalizo exclusivamente a articulação dos interesses do empresariado industrial durante o processo de produção legislativa de âmbito federal. Dessa maneira, sigo o caminho aberto pelos autores que primeiro apontaram para o fato de que a redemocratização do Brasil, a partir de meados da década de 1980, resultou no incremento das prerrogativas e da relevância política do Congresso Nacional, atraindo para esse fórum a atuação de setores sociais - entre eles o empresariado industrial - cuja atenção estava concentrada prioritariamente em processos decisórios internos do Poder Executivo (Aragão, 1994; 1996; 2000; Diniz e Boschi, 1999; 2000).

É inviável reconstituir em todos os detalhes possíveis o processo de articulação dos interesses do empresariado industrial durante a tramitação de qualquer proposição legislativa. A principal fonte de informação sobre a atividade política da indústria que utilizo neste artigo é o LEGISDATA, banco de dados eletrônico que a CNI mantém e atualiza diariamente ${ }^{5}$. Ele é composto por informações referentes ao lobby da indústria em face de milhares de proposições legislativas que interessam ao setor e que tramitaram ou ainda estão tramitando na Câmara dos Deputados, no Senado Federal ou no Congresso Nacional. Dentre todas as proposições que formam o LEGISDATA, concentro a atenção especificamente em um subgrupo: aquelas que figuram nas Agendas Legislativas da Indústria. Não é possível afirmar que o LEGISDATA contenha a descrição completa e exaustiva da articulação dos interesses do empresariado industrial ao longo da tramitação 
dessas proposições. No entanto, o artigo representa um esforço para explorar esse material de conteúdo riquíssimo e inédito.

A indústria realiza intensa ação política durante a tramitação das propostas que figuram nas Agendas Legislativas. As atividades realizadas pela indústria podem ser classificadas em cinco categorias: acompanhamento, análise, tomada de posição, orientação e pressão.

Em primeiro lugar, a indústria desenvolve um acompanhamento minucioso de cada passo da tramitação das matérias de interesse do setor nas Casas do Legislativo federal.

Em segundo lugar, a indústria analisa detalhadamente cada uma das proposições legislativas. O processo de análise é contínuo, ou seja, o objeto da análise não são apenas as proposições originais. Cada vez que uma alteração é introduzida durante a tramitação do projeto que está sob foco - o que ocorre quando são apresentados substitutivos ou emendas, em comissões ou em plenário -, a indústria prepara nova análise, destacando o significado da alteração introduzida à luz dos interesses do setor. As análises são elaboradas por técnicos (advogados, economistas, entre outros) que focalizam as proposições de acordo com sua especialização. Freqüentemente um mesmo projeto é objeto da análise de vários técnicos com especialidades diferentes. Tendo em vista o que concebem como interesses da indústria, os técnicos recomendam posições a serem tomadas pelos que contratam seus serviços. Amiúde as análises são acompanhadas por propostas alternativas sob a forma de emendas ou projetos completos.

Em terceiro, a indústria adota uma posição diante de cada projeto, tendo como base a análise técnica. A posição tomada pela indústria em relação a cada proposta pode ser contrária; contrária, com ressalvas; neutra; favorável, com ressalvas ou favorável. A posição que a indústria toma sobre um projeto pode ser alterada por diversas razões. A mudança de posição pode estar ligada à adoção de um projeto substitutivo, à introdução de emendas no projeto original ou ao surgimento de projetos novos apensados ao projeto original. A indústria pode ser totalmente contrária a um projeto em um determinado momento (ou ter ressalvas pontuais em relação a ele) e, em um momento seguinte, passar a favorecê-lo, ao perceber que alternativas piores podem ser adotadas. A situação inversa pode acontecer com um projeto ao qual a indústria é, a princípio, favorável. Em um momento seguinte, a in- 
dústria pode deixar de apoiá-lo, ao vislumbrar a possibilidade de uma alternativa melhor. A mudança de posição em qualquer sentido possível pode estar ligada também ao surgimento de novas informações, ponderações e pareceres.

A quarta atividade é a orientação. Os alvos principais dessa atividade são as próprias entidades que representam o setor industrial. A idéia é disseminar o resultado das análises técnicas das proposições legislativas, informar o que está em jogo, justificar a posição tomada e conformar no âmbito do setor uma avaliação homogênea das proposições.

Em quinto lugar, a indústria desenvolve um esforço de pressão política. A prática da pressão corresponde diretamente à articulação de interesses, ou seja, à apresentação de demandas aos tomadores de decisão. Pelo acima exposto, fica claro que a pressão é a ação em que culmina todo o longo envolvimento anterior da indústria com o processo de produção legislativa. A pressão política pode ocorrer em diversos estágios da produção legislativa: no estágio de discussão dos projetos nas duas Casas do Congresso Nacional, no de votação dos projetos nas comissões ou no plenário, no da sanção (ou veto) presidencial, ou ainda no estágio da votação pelos parlamentares de eventuais vetos do presidente. A pressão política em defesa dos interesses do empresariado industrial é exercida algumas vezes "por dentro" do processo de produção legislativa, o que ocorre quando os tomadores de decisão convidam oficialmente as entidades que representam os interesses do setor industrial para participar de audiências públicas ou reuniões de trabalho e apresentar sua posição. Outras vezes a pressão política é realizada "por fora" do processo normal de produção legislativa, nos casos em que os contatos com os tomadores de decisão não ocorrem em encontros oficiais e em que a iniciativa é tomada, em geral, pelos representantes da indústria.

Quando uma proposição está tramitando na Câmara dos Deputados, no Senado Federal ou no Congresso Nacional, a estratégia de pressão adotada pela indústria é determinada pelas regras do regimento interno dessas instituições, que organizam o trabalho legislativo e que designam os parlamentares que irão desempenhar papéis-chave no processo de negociação em torno da proposição. Os regimentos internos da Câmara, do Senado e do Congresso estabelecem, por exemplo, que uma parte significativa do trabalho legislativo seja realizado no 
âmbito de comissões temáticas - permanentes ou temporárias. Naturalmente, portanto, grande parte do esforço de pressão política realizado pelo empresariado industrial ocorre quando as proposições estão tramitando nas comissões. Nessa instância, os relatores são um alvo privilegiado da ação política da indústria.

O esforço de pressão política também ocorre quando as proposições estão tramitando no plenário da Câmara, do Senado ou do Congresso. Quando o projeto está em plenário, os representantes da indústria geralmente entram em contato com os líderes do governo e dos partidos, tendo em vista a aprovação ou rejeição do projeto. Dependendo do caso, os representantes da indústria pressionam os líderes pela rejeição ou aprovação - total ou parcial - de eventuais projetos substitutivos, projetos apensados ou emendas. A estratégia de pressão adotada pela indústria quando a proposição está em plenário a ponta para a importância dos líderes partidários no trabalho do Legislativo federal, algo que já tem sido destacado em estudos recentes sobre as relações entre o Poder Executivo e o Poder Legislativo no Brasil (Figueiredo e Limongi, 2000). O ponto que enfatizo é que as regras que distribuem o poder no interior do Legislativo brasileiro interferem não somente sobre as estratégias perseguidas pelo Poder Executivo para promover sua agenda no Congresso, mas também sobre as estratégias adotadas pelos grupos de interesse em suas atividades de pressão. A estratégia da indústria é uma evidência de que os interesses organizados, em seus cálculos políticos, já trabalham com a expectativa de que o comportamento dos parlamentares no momento da votação será disciplinado. Afinal de contas, o contato com as lideranças partidárias é realizado porque há a expectativa de que estas irão orientar o voto de suas bancadas e de que as bancadas irão acompanhar sua orientação. Se a indústria esperasse que os parlamentares se comportassem de maneira indisciplinada, a estratégia dominante provavelmente seria o contato com os parlamentares em base individual, o que, presumivelmente, envolveria maior dispêndio de tempo e outros recursos.

Os poderes legislativos conferidos pela Constituição brasileira ao chefe do Poder Executivo permitem que ele desempenhe um papel de relevância crucial no processo de produção legislativa federal do país. Sendo assim, a indústria possui forte incentivo para dirigir suas atividades de pressão política para o Executivo. As atividades de pressão não se restringem aos diversos casos em que ele é o autor da 
proposição sob análise. As atividades de pressão sobre o Executivo também ocorrem durante a negociação em torno de proposições apresentadas por parlamentares mas cujo conteúdo envolve diretamente, de uma maneira ou de outra, segmentos do Executivo. Nos muitos casos em que o setor industrial exerce pressão sobre o Executivo, esta pode ocorrer no momento em que a proposição está sendo redigida; durante o processo de negociação do projeto no parlamento ou no momento em que o presidente irá sancionar ou vetar (total ou parcialmente) uma proposição aprovada pelo Poder Legislativo (Mancuso, 2003).

Ao verificar que as entidades empresariais realizam uma intensa atividade de pressão ao longo do processo de produção legislativa, este artigo agrega evidências para confirmar o que outros cientistas políticos brasileiros já chamaram a atenção anteriormente (Vianna, 1994; 1998; Diniz e Boschi, 1999): o padrão de atuação daquelas entidades cada vez mais lembra o lobby americano, fenômeno usualmente associado a sistemas pluralistas e considerado atípico em sistemas de corporativismo de Estado.

\section{O SUCESSO POLÍTICO DA INDÚSTRIA: MÉTODO DE MENSURAÇÃO}

Esta seção apresenta o método formulado para avaliar em que medida os resultados do processo legislativo correspondem efetivamente aos interesses da indústria. Os casos focalizados são os projetos que figuram nas Agendas Legislativas publicadas entre 1996 e 2003 e cuja tramitação foi encerrada até o dia 23 de dezembro de 2003, último dia de trabalho do parlamento brasileiro naquele ano.

O Quadro 1 expõe os critérios adotados para classificar os diversos tipos de decisão como sucessos ou insucessos da indústria ${ }^{6}$. Existem cinco modalidades de decisão que encerram definitivamente a tramitação de uma proposição legislativa: esta pode ser transformada em norma jurídica; prejudicada (a proposição em questão perde a oportunidade por causa de decisão referente a outra proposição); rejeitada (em comissões com poder terminativo, no plenário da Câmara, do Senado ou do Congresso Nacional); retirada pelo autor ou arquivada ao final da legislatura ${ }^{7}$.

Quando uma proposição legislativa é transformada em norma jurídica e a posição da indústria em relação à versão final do projeto é favo- 


\section{Quadro 1}

Critérios Utilizados para Classificar Decisões como

Sucessos ou Insucessos da Indústria

\begin{tabular}{|l|l|c|}
\hline Decisão & $\begin{array}{c}\text { Posição da Indústria na } \\
\text { Deliberação Final }\end{array}$ & Resultado \\
\hline Nova norma jurídica & Favorável & Sucesso \\
Nova norma jurídica & Favorável, com ressalvas & Sucesso \\
Nova norma jurídica & Contrária, com ressalvas & Insucesso \\
Nova norma jurídica & Contrária & Insucesso \\
Prejudicada & Favorável & Sucesso \\
Prejudicada & Favorável, com ressalvas & Sucesso \\
Prejudicada & Contrária, com ressalvas & Insucesso \\
Prejudicada & Contrária & Insucesso \\
Rejeitada & Contrária & Sucesso \\
Rejeitada & Contrária, com ressalvas & Sucesso \\
Rejeitada & Favorável, com ressalvas & Insucesso \\
Rejeitada & Favorável & Insucesso \\
Retirada pelo autor & Contrária & Sucesso \\
Retirada pelo autor & Contrária, com ressalvas & Sucesso \\
Retirada pelo autor & Favorável, com ressalvas & Insucesso \\
Retirada pelo autor & Favorável & Insucesso \\
Arquivada & Contrária & Sucesso \\
Arquivada & Contrária, com ressalvas & Sucesso \\
Arquivada & Favorável, com ressalvas & Insucesso \\
\hline
\end{tabular}

rável, com ou sem ressalvas, então a decisão é contada como um exemplo de sucesso. Por outro lado, se a posição da indústria é contrária, com ou sem ressalvas, à proposição transformada em norma jurídica, então a decisão é contada como um insucesso.

Exatamente o mesmo critério é válido para o caso das proposições que foram prejudicadas pela aprovação de outras propostas. Se a posição da indústria em relação ao projeto que de fato foi aprovado é favorável, com ou sem ressalvas, então a decisão é considerada um caso de sucesso. Se a posição da indústria é contrária, com ou sem ressalvas, então a decisão é considerada um caso de insucesso. Quando a aprovação de um projeto prejudica simultaneamente duas ou mais proposições, a decisão é classificada apenas uma vez, para evitar a múltipla contagem do mesmo evento.

O inverso ocorre nos outros três casos. Se a posição da indústria é favorável a um projeto, com ou sem ressalvas, e ele é rejeitado, retirado pelo 
autor ou arquivado ao final da legislatura, então a decisão deve ser entendida como um insucesso da indústria. Por outro lado, se a posição da indústria é contrária ao projeto, com ou sem ressalvas, e o projeto é rejeitado, retirado ou arquivado, então a decisão deve ser concebida como um sucesso político da indústria ${ }^{8}$.

Quadro 2

Impacto dos Casos de Sucesso sobre o Custo Brasil

\begin{tabular}{|l|l|}
\hline Decisão & Impacto sobre o Custo Brasil \\
\hline Nova norma jurídica & Reduz o custo Brasil \\
Prejudicada por nova norma jurídica & Reduz o custo Brasil \\
Rejeitada & Impede o aumento do custo Brasil \\
Retirada pelo autor & Impede o aumento do custo Brasil \\
Arquivada ao fim da legislatura & Impede o aumento do custo Brasil \\
\hline
\end{tabular}

O Quadro 2 mostra que os sucessos políticos da indústria podem ser divididos em dois grupos, no que diz respeito ao impacto que exercem sobre o custo Brasil. O primeiro grupo é formado pelos sucessos que efetivamente reduzem o custo Brasil. É o que ocorre, por exemplo, quando um projeto apoiado pela indústria se torna norma jurídica. $\mathrm{O}$ mesmo ocorre quando um projeto é prejudicado pela aprovação de outro projeto que a indústria apóia. Ambos os casos envolvem um ganho concreto, ou seja, uma mudança do status quo para melhor, de acordo com o ponto de vista dos industriais. Os sucessos que formam o segundo grupo possuem um significado diferente. Esses sucessos impedem o aumento do custo Brasil. Este tipo de sucesso acontece quando a indústria é contrária a uma proposição e esta é rejeitada, retirada ou arquivada. Todos os casos envolvem um alívio para a indústria, porquanto havia um risco real de piora do status quo, mas este foi mantido, em vez de piorar.

Quadro 3

Impacto dos Casos de Insucesso sobre o Custo Brasil

\begin{tabular}{|l|l|}
\hline Decisão & Impacto sobre o Custo Brasil \\
\hline Nova norma jurídica & Aumenta o custo Brasil \\
Prejudicada por nova norma jurídica & Aumenta o custo Brasil \\
Rejeitada & Impede a redução do custo Brasil \\
Retirada pelo autor & Impede a redução do custo Brasil \\
Arquivada ao fim da legislatura & Impede a redução do custo Brasil \\
\hline
\end{tabular}


O Quadro 3 ilustra que os insucessos políticos da indústria também podem ser divididos em dois grupos, no que tange ao efeito que exercem sobre o custo Brasil. Os insucessos que compõem o primeiro grupo consistem em insucessos que aumentam o custo Brasil. Este tipo de insucesso ocorre quando uma proposição se torna norma jurídica e a indústria é contrária à proposição. Ele também se dá quando um projeto é prejudicado pela aprovação de outro projeto que a indústria rejeita. Na perspectiva do empresariado industrial, em ambos os casos houve uma perda, porque o status quo mudou para pior. Nos outros três casos, algo diferente tem lugar. Os insucessos que constituem o segundo grupo impedem a redução do custo Brasil. Eles acontecem quando os empresários do setor industrial favorecem proposições que vêm a ser rejeitadas, retiradas ou arquivadas. Nesses casos, havia uma oportunidade de melhora do status quo e a oportunidade não foi aproveitada. O resultado para a indústria é a frustração, posto que o status quo foi mantido, em vez de melhorar.

A discussão desenvolvida nos parágrafos anteriores é sintetizada no Quadro 4.

Quadro 4

Impacto dos Casos de Sucesso e Insucesso sobre o Custo Brasil

\begin{tabular}{|c|c|c|}
\hline \multirow{2}{*}{ Resultado da Decisão } & \multicolumn{2}{|c|}{ Impacto sobre o Status Quo } \\
\cline { 2 - 3 } & $\begin{array}{c}\text { Status Quo Muda } \\
\text { (Normas Jurídicas Novas) }\end{array}$ & $\begin{array}{c}\text { Status Quo É Mantido } \\
\text { Proposições Rejeitadas, Re- } \\
\text { tiradas, Arquivadas) }\end{array}$ \\
\hline Sucesso & $\begin{array}{c}\text { Reduz } \\
\text { o custo Brasil } \\
\text { (ganho) }\end{array}$ & $\begin{array}{c}\text { Impede o aumento } \\
\text { do custo Brasil } \\
\text { (alívio) }\end{array}$ \\
\hline Insucesso & $\begin{array}{c}\text { Aumenta } \\
\text { o custo Brasil } \\
\text { (perda) }\end{array}$ & $\begin{array}{c}\text { Impede a redução } \\
\text { do custo Brasil } \\
\text { (frustração) }\end{array}$ \\
\hline
\end{tabular}

Antes de passar à discussão dos resultados, é oportuno reconhecer um limite inerente ao método adotado, que pode ser resumido da seguinte forma: verificar a ocorrência de um sucesso não corresponde a dizer que o sucesso ocorreu por causa da influência política da indústria. 
O conceito de influência possui conotação causal. Dizer que o ator $A$ influencia o ator $B$ no que diz respeito à decisão $x$ é dizer que o comportamento de $B$ no caso da decisão $x$ se altera no sentido desejado por $A$. O desejo de $A$ é a causa, o comportamento de $B$ é o efeito (Dahl, 1988:26-27). A base de todo argumento causal é o raciocínio contrafactual (King et alii, 1994:76-82). Dessa forma, afirmar que a influência de um ator é a causa de uma decisão observada envolve afirmar que aquela decisão não decorreu de outros fatores e que, portanto, não teria acontecido - ou seria diferente - caso o ator não tivesse exercido sua influência.

Tomemos como exemplo os cinco tipos de decisão que encerram definitivamente a tramitação de uma proposição legislativa: o arquivamento ao final da legislatura, a retirada pelo autor, a rejeição, a aprovação de outra proposição que a prejudique ou a transformação em norma jurídica. Nos três primeiros tipos de decisão, atribuir os casos de sucesso à influência da indústria corresponderia a dizer que, em vez de qualquer outro fator, foi o lobby contrário às proposições legislativas que determinou o arquivamento, a retirada ou a rejeição das propostas. Nos dois tipos de decisão restantes, atribuir os casos de sucesso à influência da indústria consistiria em afirmar que, em vez de qualquer outro fator, foi o lobby favorável às proposições legislativas efetivamente aprovadas que provocou a aprovação daquelas proposições. No entanto, em nenhuma circunstância as informações produzidas pela aplicação do método autorizam o raciocínio contrafactual de que os sucessos políticos da indústria não teriam ocorrido caso a indústria não tivesse realizado seu lobby, seja ele defensivo ou ofensivo. Portanto, as informações geradas pelo método não permitem atribuir o resultado do processo legislativo à influência da indústria.

\section{O SUCESSO POLÍTICO DA INDÚSTRIA: RESULTADOS}

A Tabela 3 contém as decisões classificadas no artigo como êxitos ou malogros políticos da indústria. De um total de 216 casos, 66 decisões $(30,6 \%)$ resultaram em normas jurídicas novas ${ }^{9} ; 37$ projetos $(17,1 \%)$ foram rejeitados mediante decisões tomadas em comissões ou no plenário da Câmara, do Senado ou do Congresso Nacional; 21 proposições $(9,7 \%)$ foram retiradas de tramitação por iniciativa do próprio autor e 92 propostas $(38,8 \%)$ foram arquivadas na Câmara ou no Senado ao final da legislatura. 
Tabela 3

Decisões Classificadas como Sucessos ou Insucessos da Indústria

\begin{tabular}{l|c}
\hline & Total (\%) \\
\cline { 2 - 2 } Novas normas jurídicas & $66(30,6)$ \\
Proposições rejeitadas & $37(17,1)$ \\
Proposições retiradas pelo autor & $21(9,7)$ \\
Proposições arquivadas ao final da legislatura & $92(42,6)$ \\
\hline Total & $\mathbf{2 1 6}(\mathbf{1 0 0 , 0 )}$ \\
\hline
\end{tabular}

Fontes: SICON-SF e LEGISDATA.

A Tabela 4 apresenta os resultados obtidos com o emprego do método exposto anteriormente para identificar os sucessos e insucessos da indústria ${ }^{10}$.

Tabela 4

Resultado da Decisão por Tipo de Decisão

\begin{tabular}{l|c|c|c|c|c}
\hline & $\begin{array}{c}\text { Normas } \\
\text { Jurídicas }\end{array}$ & Rejeitadas & Retiradas & Arquivadas & Total \\
\hline Sucesso & $54(81,8)$ & $24(64,9)$ & $10(47,6)$ & $56(60,9)$ & $\mathbf{1 4 4}(\mathbf{6 6 , 7 )}$ \\
& 3,1 & $-0,3$ & $-1,9$ & $-1,6$ & \\
\hline Insucesso & $12(18,2)$ & $13(35,1)$ & $11(52,4)$ & $36(39,1)$ & $\mathbf{7 2}(\mathbf{3 3}, 3)$ \\
& $-3,1$ & 0,3 & 1,9 & 1,6 & \\
\hline Total & $\mathbf{6 6 ( 1 0 0 , 0 )}$ & $\mathbf{3 7 ( 1 0 0 , 0 )}$ & $\mathbf{2 1 ( 1 0 0 , 0 )}$ & $\mathbf{9 2} \mathbf{( 1 0 0 , 0 )}$ & $\mathbf{2 1 6} \mathbf{( 1 0 0 , 0 )}$ \\
\hline
\end{tabular}

Fontes: SICON-SF, LEGISDATA e Agendas Legislativas da Indústria.

$\chi^{2}=11,692(0,009)$.

A última coluna da Tabela 4 informa que, independentemente do tipo de decisão final tomada, a indústria obtém sucesso em nada menos que $66,7 \%$ dos casos considerados (144 sucessos para um total de 216 decisões). No geral, portanto, exatamente dois casos de sucesso ocorrem para cada caso de insucesso vivido pelo setor. Há evidências sólidas contra a hipótese de que não existe associação entre o tipo de decisão final e o resultado alcançado pela indústria. De fato, o teste qui-quadrado indica que é muito baixa $(0,009)$ a chance de erro em respaldar a hipótese alternativa de que o tipo de decisão final e o resultado obtido pelo empresariado industrial estão associados ${ }^{11}$.

A análise dos resíduos ajustados indica que, entre as novas normas jurídicas, há significativamente mais casos de sucesso para a indústria do que seria esperado se não houvesse qualquer associação entre o 
tipo de decisão final e o resultado alcançado pelo setor ${ }^{12}$. Para os outros três tipos de decisão, os resíduos ajustados não sustentam a afirmação de que há significativamente mais - ou significativamente menos - casos do que seria esperado se as duas variáveis não fossem associadas. Entre as proposições rejeitadas e as proposições arquivadas ao final da legislatura, a porcentagem de sucessos é bem maior do que a porcentagem de insucessos (respectivamente, $64,9 \%$ contra $35,1 \% \mathrm{e}$ $60,9 \%$ contra $39,1 \%)$, mas é ligeiramente inferior ao que ocorre em geral $(66,7 \%$ contra $33,3 \%)$. Apenas entre as proposições retiradas pelo próprio autor é possível notar uma pequena prevalência de insucessos sobre sucessos $(52,4 \%$ contra $47,6 \%)$.

Tabela 5

Resultado da Decisão por Impacto sobre o Status Quo

\begin{tabular}{l|c|c|c}
\hline & Muda o Status Quo & Mantém o Status Quo & Total \\
\hline Sucesso & $54(37,5)$ & $90(62,5)$ & $\mathbf{1 4 4}(\mathbf{1 0 0 , 0 )}$ \\
Insucesso & $12(16,7)$ & $60(83,3)$ & $\mathbf{7 2 ( 1 0 0 , 0 )}$ \\
\hline Total & $\mathbf{6 6}(30,6)$ & $\mathbf{1 5 0}(69,4)$ & $\mathbf{2 1 6}(\mathbf{1 0 0 , 0 )}$ \\
\hline
\end{tabular}

Fontes: SICON-SF, LEGISDATA e Agendas Legislativas da Indústria.

$\chi^{2}=9,818(0,002), \varphi=0,213(0,002)$

A Tabela 5 rearranja as informações oferecidas pela Tabela 4, para enfatizar o impacto que os casos de sucesso ou insucesso da indústria exercem sobre o custo Brasil. A Tabela 5 é baseada no Quadro 4. A primeira linha da tabela mostra que $37,5 \%$ dos sucessos políticos da indústria (54 sucessos) são obtidos com a aprovação de normas jurídicas novas que reduzem o custo Brasil, e, portanto, representam ganhos concretos para o segmento, pois mudam para melhor o status quo. A primeira linha mostra também que $62,5 \%$ dos sucessos políticos da indústria (90 sucessos) possuem uma natureza diferente. Não representam ganhos diretos para o setor, mas produzem alívio por meio da rejeição, retirada ou arquivamento de propostas que, se aprovadas, aumentariam o custo Brasil e mudariam o status quo para pior.

A segunda linha reúne os insucessos. Destes, 16,7\% (12 insucessos) representam perdas reais para a indústria, dada a aprovação de normas jurídicas que o setor desaprova. Tais fracassos pioram o status quo e aumentam o custo Brasil. No entanto, 83,3\% dos insucessos (60 insucessos) são de outro tipo e consistem em oportunidades desperdiçadas que frustram a indústria. Trata-se de projetos que reduziriam o 
custo Brasil se fossem aprovados, mas que na verdade foram rejeitados, retirados ou arquivados ao final da legislatura, preservando-se assim o status quo, em lugar de melhorá-lo.

O teste qui-quadrado sugere que é muito pequena $(0,002)$ a chance de erro em rejeitar a hipótese de desassociação entre as variáveis e em aceitar a hipótese oposta de que o resultado obtido pela indústria e o efeito da decisão política sobre o status quo estão associados. O teste phi indica que há significativamente mais casos de sucessos que mudam o status quo - e significativamente menos casos de sucesso que mantêm o status quo - do que seria esperado se não houvesse qualquer associação entre as variáveis ${ }^{13}$. A constatação é válida ainda que a freqüência de sucessos que reduzem o custo Brasil seja menor que a freqüência de sucessos que impedem o seu aumento. O teste phi indica também que há significativamente mais casos de insucessos que mantêm o status quo - e significativamente menos casos de insucessos que mudam o status quo, trazendo perdas reais - do que seria esperado se as variáveis fossem desassociadas.

Assim, a relação sucesso/insucesso entre as decisões que mudam o status quo é de 4,5 (54 sucessos para 12 insucessos), como revela a primeira coluna da Tabela 5. Ou seja, para duas decisões que representam uma perda para a indústria, há nove decisões que representam ganhos reais! A segunda coluna mostra que a relação sucesso/insucesso entre as decisões que mantêm o status quo é de 1,5 (90 sucessos para 60 insucessos). Isto significa que, para duas decisões que frustram o empresariado industrial, existem três decisões que aliviam o setor. Dessa maneira, para a satisfação da indústria, não apenas os sucessos prevalecem sobre os insucessos em ambos os casos, como a chance de sucesso do setor no que diz respeito às decisões com maiores conseqüências práticas - aquelas que transformam o status quo -é três vezes maior que a chance de sucesso entre as decisões que mantêm o status quo intocado.

O elevado grau de sucesso político da indústria relativamente às decisões que mudam o status quo pode ser explicado, em grande medida, pela afinidade do setor com a versão final das proposições de autoria do Poder Executivo, Poder da União que exerce preponderância na produção legislativa nacional. 
De fato, trabalhos recentes têm mostrado de maneira inequívoca que o Poder Executivo domina a produção legislativa federal no Brasil (Figueiredo e Limongi, 2000; 2001). De acordo com esses trabalhos, a capacidade dos presidentes brasileiros de ditar a agenda do parlamento decorre de dois fatores.

Em primeiro lugar, decorre dos amplos poderes legislativos que a Constituição de 1988 outorgou ao Poder Executivo. O presidente pode editar medidas provisórias que surtem efeito a partir de sua edição, provocando alteração imediata do status quo; pode solicitar urgência para seus projetos, forçando assim, unilateralmente, a apreciação das proposições que apresenta dentro de um prazo determinado; e pode vetar parcial ou totalmente as proposições que o parlamento envia à sua sanção. Além disso, o presidente possui a prerrogativa exclusiva de iniciar a legislação relativa à administração federal e de formular o projeto anual de orçamento, que os parlamentares podem emendar mas cujo limite de gastos não pode ser ampliado.

Em segundo lugar, a capacidade decorre do uso de recursos políticos para construir coalizões de apoio majoritárias no parlamento. Nesse ponto, o papel dos líderes partidários é crucial. Os presidentes negociam uma troca com os líderes dos partidos políticos que formarão sua base de apoio: oferecem controle sobre cargos na administração e influência política no governo em contrapartida ao apoio das agremiações. A posse desses recursos torna os líderes capazes de premiar os parlamentares leais e de punir os correligionários infiéis à orientação do partido. Assim, os líderes têm condição de cumprir, por meio da disciplina partidária, com a sua parte do acordo: garantir o apoio de seus partidos às propostas do Executivo. Contando com poderes legislativos extensos e com a disciplina de uma base aliada majoritária, o presidente pode, em grande medida, determinar as proposições que serão consideradas pelo Legislativo federal e quando elas serão consideradas.

É verdade que os autores da tese da dominância do Executivo na produção legislativa nacional a formularam tendo em mente um objetivo específico: refutar a idéia amplamente disseminada de que as instituições políticas brasileiras - especialmente a combinação rara de presidencialismo, multipartidarismo e representação proporcional com lista aberta - são incompatíveis com a governabilidade. Não obstante, utilizarei a mesma tese tendo em vista um problema diferente: en- 
tender a relação que existe entre a dominância do Executivo e a sorte política dos interesses organizados - neste caso, os interesses do empresariado industrial. Ao fazer isso, acompanho uma das sugestões oferecidas por King et alii (1994:17) para tornar um esforço de pesquisa isolado em uma contribuição para a acumulação de conhecimento: mostrar que uma tese formulada para um propósito particular pode ser aplicada para iluminar outras questões, que vão além daquelas que lhe deram origem.

Em um cenário marcado pela preponderância do Executivo na produção legislativa em geral, é razoável supor que a mesma preponderância irá reproduzir-se no subconjunto das normas jurídicas que mais interessam à indústria. Assim, a sorte da indústria no que tange às decisões políticas que mudam o status quo irá depender, em grande medida, da congruência entre sua posição e os textos resultantes de projetos do Poder Executivo. Sucessos que produzem ganhos tangíveis ocorrerão amiúde caso o nível de congruência seja alto; insucessos que acarretam perdas serão freqüentes caso o nível de congruência seja reduzido.

Tabela 6

Origem dos Projetos por Resultado da Decisão e Impacto sobre o Status Quo

\begin{tabular}{|c|c|c|c|c|c|}
\hline & \multicolumn{2}{|c|}{ Sucesso } & \multicolumn{2}{|c|}{ Insucesso } & \multirow[b]{2}{*}{ Total } \\
\hline & $\begin{array}{c}\text { Muda o } \\
\text { Status Quo }\end{array}$ & $\begin{array}{l}\text { Mantém o } \\
\text { Status Quo }\end{array}$ & $\begin{array}{c}\text { Muda o } \\
\text { Status Quo }\end{array}$ & $\begin{array}{c}\text { Mantém o } \\
\text { Status Quo }\end{array}$ & \\
\hline \multirow[t]{2}{*}{ Executivo } & $45(83,3)$ & $08(08,9)$ & $09(75,0)$ & $10(16,7)$ & $72(33,3)$ \\
\hline & 9,0 & $-6,4$ & 3,2 & $-3,2$ & \\
\hline \multirow[t]{2}{*}{ Legislativo } & $09(16,7)$ & $82(91,1)$ & $03(25,0)$ & $50(83,3)$ & $144(66,6)$ \\
\hline & $-9,0$ & 6,4 & $-3,2$ & 3,2 & \\
\hline Total & $54(100,0)$ & $90(100,0)$ & $12(100,0)$ & $60(100,0)$ & $216(100,0)$ \\
\hline
\end{tabular}

Fontes: SICON-SF, LEGISDATA e Agendas Legislativas da Indústria.

$\chi^{2}=101,825(0,000)$.

Efetivamente, o que se verifica na produção legislativa em geral também se verifica entre as proposições mais importantes para o empresariado industrial, como mostra a Tabela 6. É sólida a evidência de associação entre a autoria dos projetos e o impacto das decisões finais sobre o status quo, pois o teste qui-quadrado sugere que é minúscula $(0,000)$ a chance de erro envolvida em afirmar que tal associação existe. Dentre as decisões que resultam em normas jurídicas novas e, por- 
tanto, mudam o status quo - sejam elas classificadas como sucessos ou insucessos da indústria -, as decisões referentes a projetos do Poder Executivo predominam nitidamente sobre as referentes a projetos do Poder Legislativo. No caso particular dos sucessos, a proporção de decisões relativas a projetos do Executivo chega a 83,3\% (45 em 54), enquanto no caso dos insucessos a proporção corresponde a $75 \%$ (9 em 12). A análise dos resíduos ajustados indica que, em ambos os casos, há significativamente mais decisões relativas a projetos do Executivo do que seria esperado se a origem dos projetos e o impacto das decisões finais sobre o status quo não estivessem associados. A magnitude dos resíduos ajustados indica que a diferença entre a quantidade de casos observados e esperados é muito mais ampla entre os sucessos do que entre os insucessos.

Assim, a vantagem crucial da indústria é que, na realidade, sua posição converge com as normas jurídicas resultantes de projetos do Poder Executivo na grande maioria das vezes. A primeira coluna da tabela mostra que a convergência ocorre em 45 casos, enquanto a terceira mostra que a divergência ocorre em apenas 9 casos. Ou seja, para um total de 54 normas jurídicas oriundas de projetos do Poder Executivo, a relação sucesso/insucesso é igual a 5. Em outras palavras, para cada episódio de insucesso da indústria, em que o status quo muda para pior e o custo Brasil aumenta, há cinco episódios de sucesso político do segmento, em que o status quo muda para melhor e o custo Brasil diminui ${ }^{14}$.

A tendência favorável à aprovação de projetos do Poder Executivo coexiste com a tendência contrária à a provação de projetos do Poder Legislativo. Esta afirmação é correta em geral e para o subconjunto de projetos mais relevantes para a indústria, em particular. A Tabela 6 revela que, entre as decisões que mantêm o status quo, as decisões relativas a projetos do Poder Legislativo claramente superam as relativas a projetos do Poder Executivo - independentemente da qualificação dessas decisões como sucessos ou insucessos da indústria. No caso das decisões qualificadas de sucessos, a proporção de decisões relativas a projetos do Legislativo atinge a elevadíssima marca de $91,1 \%$ (82 em 90), enquanto no caso dos insucessos a proporção é de $83,3 \%$ (50 em 60). A análise dos resíduos ajustados indica que, nos dois casos, há significativamente mais decisões referentes a projetos do Legislativo do que seria esperado em caso de independência entre a origem 
dos projetos e o impacto das decisões finais sobre o status quo. A magnitude dos resíduos ajustados indica que a diferença entre a quantidade de casos observados e esperados é bem maior entre os sucessos do que entre os insucessos.

Dessa forma, na maior parte das vezes em que projetos do Legislativo deixam de ser aprovados, a decisão de manter o status quo, ao invés de modificá-lo, representa um alívio para a indústria, e não uma frustração. A segunda coluna da tabela mostra que há 82 episódios em que a decisão tomada correspondeu a um alívio (62,1\% dos projetos não aprovados de parlamentares) e a quarta coluna mostra que há 50 eventos de frustração ( $37,9 \%$ dos projetos não aprovados). Ou seja, para um total de 132 decisões referentes a projetos do Legislativo que não foram aprovados, o número de sucessos é $64 \%$ maior que o número de insucessos.

Em resumo, a Tabela 6 indica que os sucessos da indústria prevalecem sobre os insucessos nas duas situações mais usuais: quando os projetos do Poder Executivo são transformados em normas jurídicas e quando os projetos do Poder Legislativo deixam de ser aprovados. Em outras palavras, a indústria é simultaneamente beneficiada pelas duas tendências predominantes no processo brasileiro de produção legislativa: de um lado, existe a tendência favorável à aprovação das propostas do Poder Executivo, e esta tendência trabalha em favor da indústria, dado o alto grau de afinidade do setor com as propostas do governo; de outro lado, existe a tendência contrária à aprovação das propostas do Legislativo, e esta tendência também trabalha em favor do segmento, uma vez que a maior parte das propostas de parlamentares é interpretada como uma ameaça, e não como uma oportunidade. Os sucessos também são mais freqüentes que os insucessos em uma situação menos comum: quando os projetos do Poder Legislativo são transformados em norma jurídica. Nos 12 casos em que isso ocorre, há 9 sucessos e 3 insucessos, o que corresponde a 3 êxitos políticos da indústria para cada malogro. Finalmente, em apenas uma circunstância se verifica um predomínio ligeiro dos insucessos sobre os sucessos: quando os projetos do Executivo deixam de ser aprovados. Nessa circunstância pouco habitual, a mencionada afinidade da agenda da indústria com a agenda do Executivo explica por que os episódios de frustração (10 observações) superam os episódios de alívio (8 observações). 
Tabela 7

Resultado da Decisão por Tema da Decisão

\begin{tabular}{l|c|c|c|c|c|c|c}
\hline & $\begin{array}{c}\text { Regulamen- } \\
\text { tação da Eco- } \\
\text { nomia }\end{array}$ & $\begin{array}{c}\text { Legisla- } \\
\text { ção Tra- } \\
\text { balhista }\end{array}$ & $\begin{array}{c}\text { Custo de } \\
\text { Financia- } \\
\text { mento }\end{array}$ & $\begin{array}{c}\text { Infra- } \\
\text { Estrutura } \\
\text { Material }\end{array}$ & $\begin{array}{c}\text { Sistema } \\
\text { Tributá- } \\
\text { rio }\end{array}$ & $\begin{array}{c}\text { Infra- } \\
\text { Estrutu- } \\
\text { ra Social }\end{array}$ & Total \\
\hline Sucesso & 43 & 47 & 5 & 13 & 22 & 14 & $\mathbf{1 4 4}$ \\
& $(61,4)$ & $(74,6)$ & $(62,5)$ & $(68,4)$ & $(57,9)$ & $(77,8)$ & $\mathbf{( 6 6 , 7 )}$ \\
\hline Insuces- & 27 & 16 & 3 & 6 & 18 & 4 & $\mathbf{7 2}$ \\
so & $(38,6)$ & $(25,4)$ & $(37,5)$ & $(31,6)$ & $(42,1)$ & $(22,2)$ & $\mathbf{( 3 3 , 3 )}$ \\
& 1,1 & $-1,6$ & 0,3 & $-0,2$ & 1,8 & $-1,0$ & \\
\hline Total & $\mathbf{7 0}$ & $\mathbf{6 3}$ & $\mathbf{8}$ & $\mathbf{1 9}$ & $\mathbf{3 8}$ & $\mathbf{1 8}$ & $\mathbf{2 1 6}$ \\
& $\mathbf{( 1 0 0 , 0 )}$ & $\mathbf{( 1 0 0 , 0 )}$ & $\mathbf{( 1 0 0 , 0 )}$ & $\mathbf{( 1 0 0 , 0 )}$ & $\mathbf{( 1 0 0 , 0 )}$ & $\mathbf{( 1 0 0 , 0 )}$ & $\mathbf{( 1 0 0 , 0 )}$ \\
\hline
\end{tabular}

Fontes: SICON-SF, LEGISDATA e Agendas Legislativas da Indústria. $\chi^{2}=5,055(0,409)$.

Os dados da Tabela 7 permitem-nos verificar que os sucessos predominam sobre os insucessos em todos os itens que compõem o custo Brasil. Dentre estes, a maior porcentagem de sucessos verifica-se entre as proposições de infra-estrutura social (educação, saúde e previdência social). Neste tema, o nível de sucesso atinge a elevada marca de $77,8 \%$ dos casos. O de sucesso também é superior ao nível geral $(66,7 \%)$ em dois outros itens do custo Brasil: entre as proposições de legislação trabalhista $(74,6 \%)$ e entre as de infra-estrutura material $(68,4 \%)$. O grau de sucesso é inferior ao nível geral entre as proposições relativas ao custo de financiamento $(62,5 \%)$, à regulamentação da atividade econômica $(61,4 \%)$ e ao sistema tributário $(57,9 \%)$. O teste qui-quadrado não oferece evidências contra a hipótese de que não há associação entre os temas das proposições e o resultado alcançado pela indústria. De fato, a chance de erro em rejeitar a hipótese nula é muito alta $(0,409)$. Assim, em nenhum item do custo Brasil há significativamente mais ou significativamente menos casos observados de sucesso ou insucesso do que seria esperado dada a hipótese de desassociação entre as variáveis.

A maior parte das entidades empresariais que participam da elaboração das Agendas Legislativas da Indústria concorda com a afirmação de que a importância de cada um dos itens que compõem o custo Brasil é aproximadamente igual - seja para o segmento industrial como um todo, seja para as empresas que cada entidade representa (Tabela 8). 
Tabela 8

Importância Relativa dos Itens do Custo Brasil para a Indústria

e para as Empresas de Cada Entidade

É aproximadamente equivalente a importância de cada um dos seis itens que compõem o custo Brasil para o setor industrial como um todo

\begin{tabular}{c|c|c}
\hline Concorda & Discorda & Total \\
$29(61,7)$ & $18(38,3)$ & $47(100,0)$ \\
\hline
\end{tabular}

É aproximadamente equivalente a importância de cada um dos seis itens que compõem o custo Brasil para as empresas que minha organização representa

\begin{tabular}{c|c|c}
\hline Concorda & Discorda & Total \\
$25(53,2)$ & $22(46,8)$ & $47(100,0)$ \\
\hline
\end{tabular}

Fonte: Questionários eletrônicos enviados para os integrantes da RedIndústria.

De tal modo, o resultado não sugere a necessidade de atribuir peso diferente aos sucessos políticos colhidos pelo empresariado industrial em cada tema do custo Brasil. Além disso, permite afirmar que a indústria não somente é mais bem-sucedida do que supõem os proponentes da tese da debilidade política, como também os seus êxitos superam os fracassos em todos os aspectos de relevância similar da agenda pró-competitividade.

O que pode ser dito quando os sucessos e insucessos da indústria em cada item do custo Brasil são avaliados quanto ao impacto que exercem sobre o status quo? Em cada item, qual é a proporção de sucessos que efetivamente mudam o status quo para melhor, ocasionando ganhos tangíveis para o empresariado industrial? Qual é a proporção de sucessos que trazem alívio para o setor, impedindo a piora do status quo? Tema por tema, a proporção de sucessos de cada tipo é sempre semelhante à proporção observada em geral, como mostra a Tabela 5? Ou há variações relevantes? Quanto aos insucessos, qual é a proporção de decisões que causam perdas reais, em cada tema? Qual é a proporção de decisões que frustram as esperanças da indústria? A proporção de insucessos de cada tipo, em cada tema, segue de perto a proporção observada na Tabela 5? As respostas para essas perguntas são dadas pela Tabela 9.

Os dados da Tabela 9 complementam as informações da Tabela 7. Os sucessos predominam sobre os insucessos em todos os itens que compõem o custo Brasil, mas o tipo de sucesso prevalecente em cada item nem sempre é o mesmo. 
Tabela 9

Resultado da Decisão por Impacto da Decisão sobre o Status Quo, Controlado por Tema da Decisão

\begin{tabular}{|c|c|c|c|c|}
\hline Tema & Resultado & $\begin{array}{c}\text { Muda o } \\
\text { Status Quo }\end{array}$ & $\begin{array}{l}\text { Mantém o } \\
\text { Status Quo }\end{array}$ & Total \\
\hline \multirow{3}{*}{ Regulamentação da Economia } & Sucesso & $26(60,5)$ & $17(39,5)$ & $43(100,0)$ \\
\hline & Insucesso & $4(14,8)$ & $23(85,2)$ & $27(100,0)$ \\
\hline & Total & $30(42,9)$ & $40(57,1)$ & $70(100,0)$ \\
\hline \multirow{3}{*}{ Legislação Trabalhista } & Sucesso & $5(10,6)$ & $42(89,4)$ & $47(100,0)$ \\
\hline & Insucesso & $1(06,2)$ & $15(93,8)$ & $16(100,0)$ \\
\hline & Total & $6(09,5)$ & $57(90,5)$ & $63(100,0)$ \\
\hline \multirow{3}{*}{ Custo de Financiamento } & Sucesso & $03(60,0)$ & $2(40,0)$ & $5(100,0)$ \\
\hline & Insucesso & - & $3(100,0)$ & $3(100,0)$ \\
\hline & Total & $3(37,5)$ & $5(62,5)$ & $8(100,0)$ \\
\hline \multirow{3}{*}{ Infra-Estrutura Material } & Sucesso & $9(69,2)$ & $4(30,8)$ & $13(100,0)$ \\
\hline & Insucesso & - & $6(100,0)$ & $6(100,0)$ \\
\hline & Total & $9(47,4)$ & $10(52,6)$ & $19(100,0)$ \\
\hline \multirow{3}{*}{ Sistema Tributário } & Sucesso & $4(18,2)$ & $18(81,8)$ & $22(100,0)$ \\
\hline & Insucesso & $5(31,2)$ & $11(68,8)$ & $16(100,0)$ \\
\hline & Total & $9(23,7)$ & $29(76,3)$ & $38(100,0)$ \\
\hline \multirow{4}{*}{ Infra-Estrutura Social } & Sucesso & $7(50,0)$ & $7(50,0)$ & $14(100,0)$ \\
\hline & Insucesso & $2(50,0)$ & $2(50,0)$ & $4(100,0)$ \\
\hline & Total & $9(50,0)$ & $9(50,0)$ & $18(100,0)$ \\
\hline & Total & $66(30,6)$ & $150(69,4)$ & $216(100,0)$ \\
\hline $\begin{array}{ll}\text { Regulamentação da } & \text { Legislação Traba- } \\
\text { Economia } & \text { lhista } \\
\chi^{2}=14,11(0,000) & \text { Fisher }=(1,000)\end{array}$ & $\begin{array}{l}\text { Custo de Finan- } \\
\text { ciamento } \\
\text { Fisher }=(0,196)\end{array}$ & $\begin{array}{l}\text { Infra-estrutura } \\
\text { Material } \\
\text { Fisher }=(0,011)\end{array}$ & $\begin{array}{l}\text { Sistema Tributá- } \\
\text { rio } \\
\text { Fisher }=(0,450)\end{array}$ & $\begin{array}{l}\text { Infra-estrutura } \\
\text { Social } \\
\text { Fisher }=(1,000)\end{array}$ \\
\hline$\varphi=0,449(0,000) \quad \varphi=0,065(0,606)$ & $\varphi=0,600(0,090)$ & $\varphi=0,645(0,005)$ & $\varphi=-0,152(0,35)$ & $\varphi=0,000(1,000)$ \\
\hline
\end{tabular}

Há dois temas em que se nota um predomínio significativo de sucessos políticos que ocasionam ganhos tangíveis para a indústria: regulamentação da economia e infra-estrutura material ${ }^{15}$. Os sucessos que alteram o status quo para melhor também são maioria entre as decisões relativas ao custo de financiamento, mas, nesse caso, a superioridade não chega a ser estatisticamente expressiva. Note-se portanto que, para esses temas específicos do custo Brasil, o tipo de sucesso predominante é diverso do tipo que prevalece para o conjunto geral das decisões, como mostra a Tabela 5. Em outros dois temas - legislação trabalhista e sistema tributário - predominam justamente os sucessos políticos defensivos, que proporcionam alívio para a indústria medi- 
ante a rejeição, retirada ou arquivamento de projetos cuja aprovação aumentaria o custo Brasil. Nesses casos, no entanto, a freqüência observada de sucessos defensivos não é significativamente maior que a freqüência esperada ${ }^{16}$. Entre as decisões referentes à infra-estrutura social, a proporção de sucessos que reduzem o custo Brasil é igual à proporção de sucessos que barram sua ampliação.

A Tabela 10 ajuda a entender por que, em alguns temas do custo Brasil, sobressaem os sucessos que conferem ganhos para o empresariado industrial, enquanto em outros temas os sucessos que causam alívio formam a maioria.

Tabela 10

Sucessos: Origem dos Projetos por Impacto da Decisão sobre o Status Quo, Controlado por Tema

\begin{tabular}{|c|c|c|c|c|}
\hline Tema & Origem & $\begin{array}{c}\text { Muda o Sta- } \\
\text { tus Quo }\end{array}$ & $\begin{array}{l}\text { Mantém o } \\
\text { Status Quo }\end{array}$ & Total \\
\hline \multirow{3}{*}{$\begin{array}{l}\text { Regulamentação da Econo- } \\
\text { mia }\end{array}$} & Executivo & $22(100,0)$ & - & $22(100,0)$ \\
\hline & Legislativo & $4(19,0)$ & $17(81,0)$ & $21(100,0)$ \\
\hline & Total & $26(60,5)$ & $17(39,5)$ & $43(100,0)$ \\
\hline \multirow{3}{*}{ Legislação Trabalhista } & Executivo & $5(41,7)$ & $7(58,3)$ & $12(100,0)$ \\
\hline & Legislativo & - & $35(100,0)$ & $35(100,0)$ \\
\hline & Total & $5(10,6)$ & $42(89,4)$ & $47(100,0)$ \\
\hline \multirow{3}{*}{ Custo de Financiamento } & Executivo & $2(100,0)$ & - & $2(100,0)$ \\
\hline & Legislativo & $1(33,3)$ & $2(66,7)$ & $3(100,0)$ \\
\hline & Total & $3(60,0)$ & $2(40,0)$ & $5(100,0)$ \\
\hline \multirow{3}{*}{ Infra-Estrutura Material } & Executivo & $7(100,0)$ & - & $7(100,0)$ \\
\hline & Legislativo & $2(33,3)$ & $4(66,7)$ & $6(100,0)$ \\
\hline & Total & $9(69,2)$ & $10(30,8)$ & $13(100,0)$ \\
\hline \multirow{3}{*}{ Sistema Tributário } & Executivo & $4(100,0)$ & - & $4(100,0)$ \\
\hline & Legislativo & - & $18(100,0)$ & $18(100,0)$ \\
\hline & Total & $4(18,2)$ & $18(81,8)$ & $22(100,0)$ \\
\hline \multirow{3}{*}{ Infra-Estrutura Social } & Executivo & $5(83,3)$ & $1(16,7)$ & $6(100,0)$ \\
\hline & Legislativo & $2(25,0)$ & $6(75,0)$ & $8(100,0)$ \\
\hline & Total & $7(50,0)$ & $7(50,0)$ & $14(100,0)$ \\
\hline Total & & $54(37,5)$ & $90(62,5)$ & $144(100,0)$ \\
\hline $\begin{array}{ll}\text { Regulamentação } & \text { Legislação Traba- } \\
\text { da Economia } & \text { lhista } \\
\chi^{2}=29,45(0,000) & \text { Fisher }=(0,001) \\
\varphi=0,828(0,000) & \varphi=0,589(0,000)\end{array}$ & $\begin{array}{l}\text { Custo de Financi- } \\
\text { amento } \\
\text { Fisher }=(0,400) \\
\varphi=0,667(0,136)\end{array}$ & $\begin{array}{l}\text { Infra-estrutura } \\
\text { Material } \\
\text { Fisher }=(0,021) \\
\varphi=0,720(0,009)\end{array}$ & $\begin{array}{l}\text { Sistema Tributá- } \\
\text { rio } \\
\text { Fisher }=(0,000) \\
\varphi=1(0,000)\end{array}$ & $\begin{array}{l}\text { Infra-estrutura } \\
\text { Social } \\
\text { Fisher }=(0,103) \\
\varphi=0,577(0,031)\end{array}$ \\
\hline
\end{tabular}


A diferença entre os temas do custo Brasil no que tange ao tipo prevalecente de sucesso deve-se, em grande medida, à origem dos projetos. A maior parte dos projetos de regulamentação da economia e infra-estrutura material que resultaram em sucessos para a indústria é de autoria do Poder Executivo. Em ambos os casos, a tendência favorável à aprovação de projetos do Executivo operou em máxima potência: todos os projetos do Executivo foram transformados em norma jurídica ${ }^{17}$. Por si só, este resultado já garantiria a superioridade dos sucessos que melhoram o status quo. Não obstante, o percentual desse tipo de sucesso foi elevado ainda mais um pouco, nos dois temas, por causa da aprovação de alguns projetos oriundos do Poder Legislativo. No caso dos projetos relativos ao custo de financiamento, os dois do Poder Executivo também foram aprovados, mas isoladamente eles seriam insuficientes para garantir o predomínio dos êxitos que reduzem o custo Brasil. Este predomínio ocorreu porque um projeto do Poder Legislativo obteve aprovação.

Por outro lado, a maior parte dos projetos relativos à legislação trabalhista e ao sistema tributário que resultaram em sucessos para a indústria é de autoria de parlamentares. A tendência contrária à aprovação de projetos do Poder Legislativo atuou plenamente nos dois itens, pois todos os projetos de deputados e senadores foram rejeitados, retirados ou arquivados, o que determinou a predominância de alívios para a indústria ${ }^{18}$.

Assim como nos outros casos, também no caso específico dos projetos de infra-estrutura social, o Poder Executivo é o autor da maior parte dos projetos transformados em normas jurídicas que melhoram o status quo, enquanto o Poder Legislativo é a origem da maior parte dos projetos que ocasionam sucessos defensivos ${ }^{19}$. Entretanto, pequenos desvios em relação às tendências predominantes do processo legislativo provocaram o equilíbrio entre os dois tipos de sucesso neste item das Agendas Legislativas da Indústria.

A permanente inferioridade dos insucessos em relação aos sucessos, independentemente do tema do custo Brasil, não é o único fato que chama a atenção. Deve-se ressaltar ainda que em nenhum tema do custo Brasil se verifica a preponderância dos insucessos políticos mais perigosos para a indústria, aqueles que impõem perdas efetivas para o setor. Em quase todos os itens das Agendas Legislativas, a grande maioria dos insucessos consiste em decisões que desapontam a in- 
dústria, por meio da rejeição, retirada ou arquivamento de projetos que ela apóia - exatamente o mesmo tipo de insucesso que prevalece no conjunto geral das decisões (Tabela 5). A exceção fica por conta das proposições de infra-estrutura social, em que a freqüência dos dois tipos de insucessos é a mesma.

A origem dos projetos também ajuda a entender por que a frustração de oportunidades é o tipo de insucesso mais freqüente em quase todos os temas do custo Brasil - como indica a Tabela 11.

\section{Tabela 11}

Insucessos: Origem dos Projetos por Impacto da Decisão sobre o Status Quo, Controlado por Tema

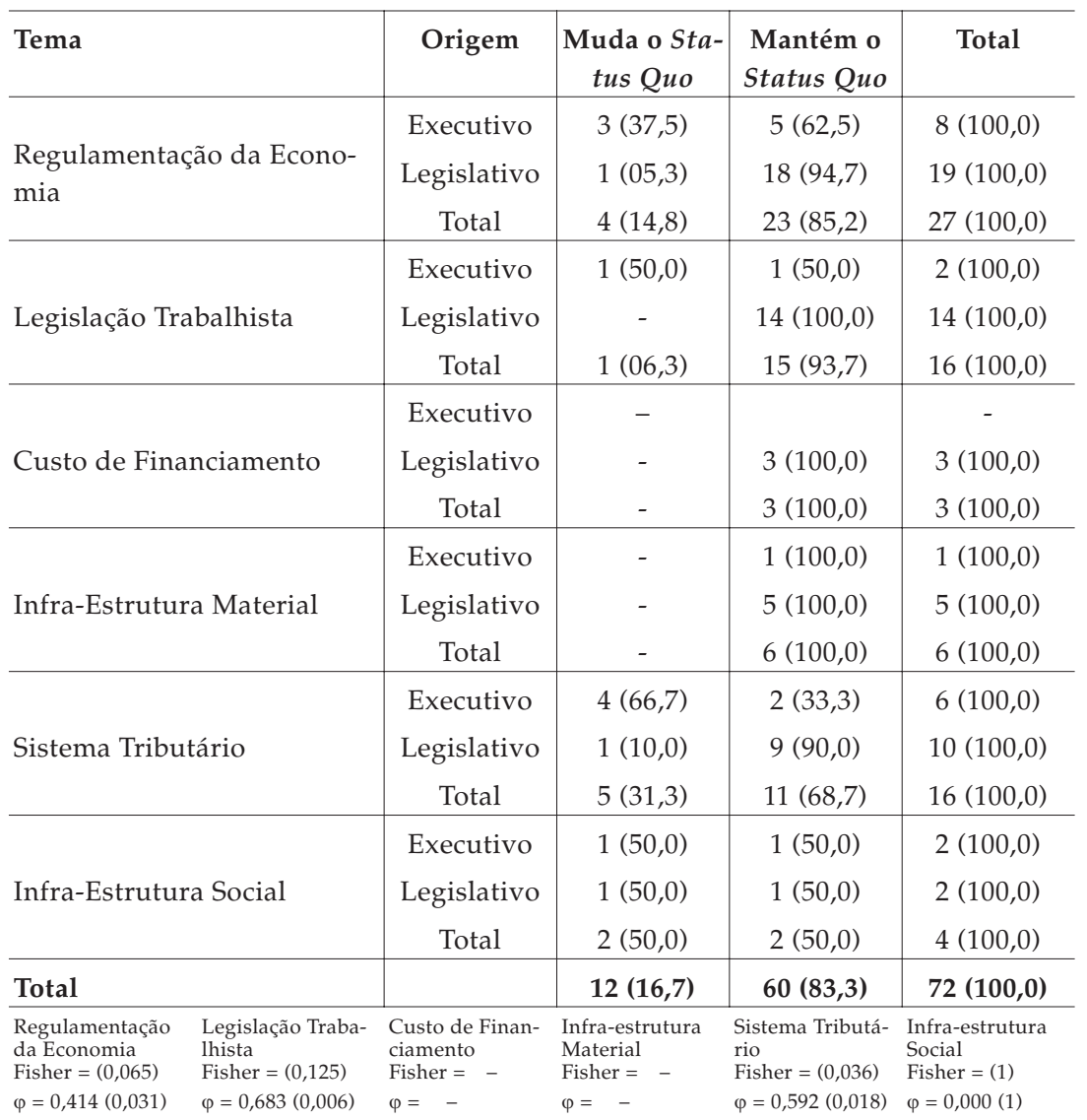

Exceto no caso dos projetos de infra-estrutura social, o Poder Legislativo é a origem da maior parte dos projetos que resultaram em insu- 
cessos para a indústria. A tendência desfavorável à aprovação dos projetos de parlamentares obrou com intensidade elevadíssima quando não em grau total - em praticamente todos os itens do custo Brasil. Deste modo, as derrotas da indústria consistiram, predominantemente, na frustração decorrente da impossibilidade de realizar os benefícios potenciais prometidos por propostas de parlamentares $^{20}$.

\section{CONCLUSÕES}

Em resumo, o empresariado industrial tem se mostrado um ator político fortemente interessado na redução do custo Brasil, ou seja, na implementação de políticas públicas que o setor julga necessárias para aprimorar a competitividade das empresas do país em comparação com empresas situadas em outros países.

Com esse propósito, os industriais têm realizado um grande trabalho coletivo para identificar, dentre os projetos que tramitam no Congresso Nacional, aqueles que possuem maior efeito potencial sobre o custo Brasil; para definir uma posição unificada diante dos projetos mais relevantes; e para promover sua posição durante o processo decisório. Tal trabalho comum é coordenado pela CNI, que divulga anualmente, desde 1996, a Agenda Legislativa da Indústria, publicação que condensa e exprime a posição do segmento.

Essas constatações vão de encontro ao que sustentam os proponentes da tese da debilidade política da indústria no Brasil, que representam os empresários do setor como inábeis para a ação coletiva e atribuem esta inabilidade, em grande medida, à presença do sistema corporativista de representação de interesses, principal responsável, ao mesmo tempo, pela fragmentação excessiva do empresariado e pela falta de representatividade das associações empresariais mais abrangentes.

Os resultados apresentados na seção anterior acrescentam evidências contra a tese da debilidade da indústria. A indústria não somente tem sido capaz de identificar projetos de lei referentes ao custo Brasil e de definir e defender seu ponto de vista em relação a eles, mas também tem obtido um índice de sucesso elevado - conclusão autorizada pelo confronto sistemático entre a posição da indústria e o teor da decisão final sobre os projetos das Agendas Legislativas que tiveram tramitação encerrada. De fato, os resultados apontam que o nível de êxito po- 
lítico da indústria é considerável: dois terços das decisões podem ser classificados como sucessos, contra um terço das decisões finais que é classificado como insucesso (Tabela 4).

Os sucessos prevalecem sobre os insucessos tanto entre as decisões que mudam o status quo - ou seja, há mais ganhos do que perdas quanto entre as decisões que mantêm o status quo - ou seja, há mais alívios do que frustrações. Os sucessos que mantêm o status quo são mais freqüentes do que os sucessos que o alteram; no entanto, a chance de sucesso da indústria entre as decisões que mudam o status quoe, portanto, têm maiores conseqüências práticas - é três vezes maior que a chance de sucesso entre as decisões que o preservam. O tipo de insucesso político mais freqüente é justamente o mais inofensivo aquele que provoca frustração de expectativas, mas não ocasiona perdas reais (Tabela 5).

Essa situação extremamente positiva para o empresariado industrial se verifica, em grande medida, porque as duas tendências principais do processo legislativo brasileiro operam em favor do segmento: por um lado, a tendência favorável à aprovação de projetos do Poder Executivo geralmente beneficia a indústria, por causa do alto grau de afinidade do setor com as normas oriundas de proposições do governo federal; por outro lado, a tendência contrária à aprovação de projetos do Poder Legislativo mais beneficia do que prejudica a indústria, porque ela avalia a maior parte das propostas apresentadas por deputados e senadores como uma ameaça aos seus interesses (Tabela 6).

Os sucessos predominam sobre os insucessos em todos os temas do custo Brasil e, apesar das variações do grau de sucesso de tema para tema, em nenhum deles a incidência observada de sucessos é significativamente inferior à incidência esperada (Tabela 7). Posto que os integrantes da RedIndústria atribuem relevância similar a todos os temas do custo Brasil - seja para a indústria como um todo, seja para as empresas que suas organizações representam -, não há nenhuma razão aparente para supor que o grau de sucesso alcançado em um tema é mais ou menos importante do que o grau de sucesso obtido em outros temas (Tabela 8).

As duas principais tendências do processo legislativo federal também ajudam a explicar o tipo predominante de sucesso e de insucesso em cada tema do custo Brasil. Em alguns temas - especialmente regu- 
lamentação da economia e infra-estrutura material - existe uma nítida superioridade dos sucessos que mudam o status quo para melhor, gerando ganhos para a indústria, em relação aos sucessos que mantêm o status quo, causando alívio. Portanto, para esses casos, o tipo usual de sucesso político é o oposto do tipo mais freqüente em geral. Em grande medida, este resultado ocorre porque a maioria dos projetos que ocasionam sucessos para a indústria é de autoria do Poder Executivo. A tendência favorável à aprovação dos projetos do Executivo, associada à afinidade da indústria com as normas jurídicas vindas de projetos do Executivo, explica a elevada freqüência de ganhos em ambos os casos. Em outros itens do custo Brasil - legislação trabalhista e sistema tributário - verifica-se uma clara preponderância dos sucessos que oferecem alívio. O resultado é explicável, em grande medida, porque a maior parte dos projetos que ocasionam sucessos é formada por projetos de parlamentares que representam um risco para os interesses da indústria, mas que estão sujeitos à tendência contrária à aprovação de projetos oriundos do Legislativo. Em praticamente todos os temas do custo Brasil - exceto infra-estrutura socialprevalece o mesmo tipo de insucesso que prevalece em geral: o insucesso menos prejudicial, que produz frustração, em vez de perdas. Isto ocorre, em grande medida, porque em quase todos os temas a maioria notável das decisões classificadas como insucessos se refere a projetos de parlamentares, que correspondiam aos interesses da indústria (Tabelas 9, 10 e 11).

O grau de sucesso obtido pelo setor industrial é muito expressivo, especialmente quando confrontado com as expectativas contrárias dos expoentes da tese da debilidade política da indústria. No entanto, é prudente reconhecer que não existem evidências suficientes para afirmar que os sucessos políticos ocorreram por causa do lobby realizado ao longo do processo legislativo pelos industriais e/ou pelos representantes de seus interesses.

Também é sensato reconhecer que o expressivo índice de sucesso político alcançado pela indústria se refere a um momento histórico preciso, situado entre a segunda metade da década de 90 e a primeira metade da década de 2000. No que diz respeito ao passado, é legítimo questionar se a indústria sempre manteve um nível tão alto de sucesso no processo legislativo federal, desde que o Congresso Nacional retomou em plenitude as suas prerrogativas políticas, com a redemocratização. Eventualmente, uma investigação de maior alcance histó- 
rico poderia constatar que a preponderância de sucessos no período analisado configura uma exceção, e não a norma. No que tange ao futuro, nada assegura que a atual situação favorável ao empresariado industrial irá continuar, nada impede que a situação mude para pior. Em política, muitas vezes as vitórias são fugazes, e o caráter dinâmico do processo político torna passível de reversão, no futuro, grande parte dos sucessos obtidos no presente por um ator social.

A argumentação desenvolvida no artigo questiona aspectos fundamentais da tese da debilidade política da indústria, que tem atingido o status de nova sabedoria convencional sobre o comportamento político do setor, especialmente entre importantes autores estrangeiros. Sob outros matizes, a mesma idéia de que a desunião e a fraqueza coletiva distinguem o empresariado industrial brasileiro já foi contestada em trabalhos anteriores, que se tornaram referências na literatura sobre a matéria (Diniz e Boschi, 1978:153-199; Leopoldi, 2000). O debate acadêmico sobre o assunto revela-se muito promissor. Há muito espaço para novos estudos sobre a organização da indústria para a ação política e sobre sua atuação efetiva diante dos Poderes Legislativo, Executivo e Judiciário em âmbito federal, estadual e local. Somente o acúmulo de estudos inspirados teoricamente e orientados empiricamente permitirá o entendimento mais preciso dos resultados alcançados por esse segmento de classe.

(Recebido para publicação em setembro de 2003)

Versão definitiva em junho de 2004)

\section{NOTAS}

1. Ao final do governo Sarney havia dezenas de regimes especiais de importação, sob os quais se dava a entrada da grande maioria de produtos estrangeiros no mercado nacional. Dentro desses regimes, as importações ocorriam com tarifas especialmente reduzidas, desde que fosse observada a Lei do Similar Nacional, que estabelecia que um produto somente poderia ser importado se ficasse comprovado que nenhum produto similar era produzido no país. Dada a prevalência de tais regimes, a redução das tarifas do imposto de importação sob o governo Sarney teve um efeito mais simbólico do que prático (Suzigan e Villela, 1997:76). 
2. A desvalorização do real a partir de 1999 contribuiu para a redução das importações (IEDI, 2002), mas o efeito da ampliação da concorrência sobre a indústria nacional já se fizera sentir ao longo de toda a década.

3. Reformas associadas à redução do custo Brasil vêm sendo realizadas desde o início da década passada, tais como privatizações, concessões de serviços públicos, desregulamentação da economia, mudanças na previdência social, mudanças no sistema tributário, entre outras. Permanece vívida a discussão sobre o impacto real dessas mudanças no custo Brasil. De qualquer maneira, hoje faz pouco sentido entender a debilidade política do empresariado industrial como uma explicação para a inexistência das reformas. Portanto, a tese figura em trabalhos mais recentes sob uma versão mitigada, em que a debilidade política do empresariado é reinterpretada como um fator que impede que a redução do custo Brasil ganhe em ritmo, abrangência e profundidade.

4. A contribuição sindical responde pela sustentação financeira de todos os níveis da estrutura corporativista, uma vez que a contribuição paga por uma empresa é distribuída entre o sindicato, a federação e a confederação que a representam (CLT, artigo 589).

5. A Coordenadoria de Assuntos Legislativos - COAL da CNI concedeu gentilmente ao pesquisador o acesso ao LEGISDATA, em um exemplo raro e louvável de transparência.

6. A posição da indústria sobre as proposições legislativas foi obtida por meio de duas fontes: as próprias Agendas Legislativas e o LEGISDATA. O teor das decisões tomadas também foi obtido em duas fontes: o LEGISDATA e o Sistema de Informações do Congresso Nacional - SICON-SF, atualizado diariamente pelo corpo técnico do PRODASEN - Serviço de Processamento de Dados do Senado Federal.

7. O regimento da Câmara (art. 105) determina o arquivamento de todas as proposições ao final da legislatura, exceto aquelas com pareceres favoráveis de todas as comissões; as já aprovadas pelo plenário em turno único, primeiro ou segundo turno; as que já tenham tramitado no Senado ou sejam dele originárias e as proposições de iniciativa popular, de iniciativa de outro Poder ou do procurador-geral da República. O regimento do Senado (arts. 332 e 333) determina o arquivamento de todas as proposições ao final da legislatura, exceto aquelas com parecer favorável das comissões e as originárias da Câmara ou por ela revisadas. As proposições em tramitação há duas legislaturas são arquivadas automaticamente.

8. As ressalvas poderiam refinar a dicotomia "sucesso X insucesso", criando-se a partir dela quatro categorias: sucesso completo e parcial (quando há ressalvas), e insucesso completo e parcial (quando há ressalvas). A principal vantagem seria destacar nuanças que previnem a concepção de sucesso ou insucesso político como uma questão de "tudo ou nada". Entretanto, a vantagem não supera a desvantagem. As duas categorias novas conteriam pouquíssimos casos, e por este motivo dificultariam sensivelmente a análise estatística dos resultados. Somente $16,7 \%$ dos sucessos (24 casos em 144) seriam classificados como sucessos parciais. Apenas 2,8\% dos insucessos (2 casos em 72) seriam classificados como insucessos parciais. Portanto, a opção por manter a dicotomia é justificável. Admita-se, todavia, que algumas decisões classificadas como sucessos não são decisões perfeitas aos olhos dos industriais, embora as imperfeições sejam insuficientes para alterar a classificação. Ao 
mesmo tempo, há decisões contabilizadas como insucessos que possuem aspectos aceitáveis pelos empresários.

9. Sessenta projetos das Agendas Legislativas foram transformados em normas jurídicas. As outras seis normas vieram de projetos que não estavam nas publicações, mas cuja aprovação prejudicou oito projetos das Agendas.

10. Para solicitar uma cópia das bases de dados que originaram as tabelas, os interessados devem enviar uma mensagem para pralon@usp.br. A base de dados está disponível em arquivos dos programas Excel, Access e SPSS.

11. Nesta tese, a hipótese de que não há associação entre as variáveis não será rejeitada quando a chance de erro tipo I (rejeitar a hipótese nula quando ela é verdadeira) for maior que 0,05 .

12. O resíduo ajustado é uma medida calculada para cada célula de uma tabela de contingência. Para cada célula, ou seja, para cada combinação entre as categorias das variáveis utilizadas, o resíduo ajustado indica se há ou não há significativamente mais (ou menos) casos do que seria esperado se as variáveis não estivessem associadas. O resíduo ajustado indica que há significativamente mais casos do que o esperado quando é maior que 1,96 . Por outro lado, o resíduo ajustado indica que há significativamente menos casos do que o esperado quando é inferior a -1,96. Quando o resíduo ajustado se situa no intervalo entre -1,96 e 1,96, não há diferença significativa entre o número de casos esperado e o número de casos observados. Para calcular os resíduos ajustados, utilizei o programa SPSS, que arredonda o valor dos resíduos, apresentando-o com apenas uma casa decimal. Portanto, o resíduo ajustado é significativo quando for igual ou maior que $|2,0|$.

13. Quando o resultado do teste phi é positivo e significativo (ou seja, quando o $p$-value é igual ou menor que 0,05 ), ele indica que há mais casos observados na diagonal principal da tabela do que seria esperado no caso de independência entre as variáveis. Quando o resultado do teste phi é negativo e significativo, ele indica que há mais casos observados na diagonal oposta do que seria esperado na hipótese de independência.

14. Das 54 normas jurídicas, $43(79,6 \%)$ vieram de projetos apresentados pelo governo Cardoso. Dessas normas, 35 são classificadas como sucessos $(81,4 \%)$, enquanto as outras 8 como insucessos $(18,6 \%)$. Os sucessos também superam os insucessos entre as 3 normas ( $5,6 \%$ do total) que vieram de projetos do governo Collor ( 2 sucessos e 1 insucesso); entre as 4 normas ( $7,4 \%$ do total) provenientes de projetos do governo Franco (4 sucessos); e entre as 4 normas $(7,4 \%)$ vindas de projetos do governo Lula (4 sucessos).

15. A chance de erro em afirmar que o resultado da decisão e o efeito da decisão sobre o status quo estão associados é ínfima para os dois temas (respectivamente, 0,000 e 0,011 ). O teste qui-quadrado de independência das variáveis não é adequado para tabelas $2 \times 2$ em que o número de casos esperados em qualquer célula seja inferior a 5 . Para essas tabelas, o SPSS examina a hipótese de independência com o teste exato de Fisher. Para os dois temas, o teste phi aponta que há mais casos de sucessos que mudam o status quo e de insucessos que o preservam do que seria esperado na ausência de associação.

16. Nos dois temas é elevada a chance de erro em afirmar a associação entre o resultado da decisão e o impacto da decisão sobre o status quo (respectivamente, 1 e 0,450). 
17. Os testes revelam que são pequenas as chances de erro em rejeitar a hipótese de independência entre a origem do projeto e o tipo de sucesso nos casos de regulamentação da economia $(0,000)$ e infra-estrutura material $(0,021)$. Nos dois casos, o teste phi indica que a diagonal principal da tabela concentra mais observações do que seria esperado se as variáveis fossem independentes.

18. Os testes apresentam evidências sólidas contra a hipótese de independência no caso dos projetos de legislação trabalhista - em que a chance de erro tipo I é igual a 0,001 - e de sistema tributário - em que a chance é igual a 0,000. Também nesses dois casos o teste phi indica que a diagonal principal da tabela concentra mais observações do que seria esperado na hipótese de independência das variáveis.

19. Neste caso, o teste exato de Fisher mostra que a chance de erro em rejeitar a hipótese de independência é igual a 0,103. A chance de erro supera o patamar estabelecido nesta tese, mas atinge um valor que é admitido em muitos trabalhos científicos.

20. Dentre todos os temas, o teste exato de Fisher oferece evidências sólidas contra a hipótese de independência apenas no caso das proposições de sistema tributário em que a chance de erro tipo I é igual a 0,036.

\section{REFERÊNCIAS BIBLIOGRÁFICAS}

ARAGÃO, Murillo de. (1994), Grupos de Pressão no Congresso Nacional: Como a Sociedade Pode Defender Licitamente seus Direitos no Poder Legislativo. São Paulo, Maltese.

. (1996), "A Ação dos Grupos de Pressão nos Processos Constitucionais Recentes no Brasil". Revista de Sociologia e Política, nos 6-7.

. (2000), Brasil e Argentina: Abordagem Comparada sobre Grupos de Pressão no Poder Legislativo. Tese de Doutorado apresentada ao Centro de Pesquisa e Pós-Graduação sobre a América Latina e Caribe da Universidade de Brasília.

ARBACHE, Jorge Saba, SOARES, Sergei e SERVO, Luciana M. Santos. (2001), “O que (Não) Sabemos sobre a Relação entre Abertura Comercial e Mercado de Trabalho no Brasil". Texto para Discussão, no 843, Brasília, IPEA.

BIELCHOWSKY, Ricardo. (1999), “Investimentos na Indústria Brasileira depois da Abertura e do Real: O Mini-Ciclo de Modernizações, 1995-1997". Série Reformas Econômicas, no 44, Comissão Econômica para a América Latina - CEPAL.

BONELLI, Regis. (1998), “A Note on Foreign Direct Investment (FDI) and Industrial Competitiveness in Brazil". Texto para Discussão, no 584, Brasília, IPEA.

. (2000), “Fusões e Aquisições no Mercosul”. Texto para Discussão, no 718, Brasília, IPEA.

. (2001), “Políticas de Competitividade Industrial no Brasil - 1995/2000". Texto para

Discussão, no 810, Brasília, IPEA. 
. (2002), "Labor Productivity in Brazil during the 1990s". Texto para Discussão, nº 906, Brasília, IPEA.

_ e GONÇALVES, Robson R. (1998), “Para Onde Vai a Estrutura Industrial Brasileira?". Texto para Discussão, no 540, Brasília, IPEA.

CASTRO, Antonio Barros de. (2001), “A Reestruturação Industrial Brasileira nos Anos 90: Uma Interpretação". Revista de Economia Política, vol. 21, no 3.

COUTINHO, Luciano e FERRAZ, João Carlos (coords.). (2002), Estudo da Competitividade da Indústria Brasileira. Campinas, Papirus.

CNI - Confederação Nacional da Indústria. (1996a), Custo Brasil. Brasília, CNI.

DAHL, Robert. (1988), Análise Política Moderna. Brasília, Editora da Universidade de Brasília.

DINIZ, Eli e BOSCHI, Renato. (1978), Empresariado Nacional e Estado no Brasil. Rio de Janeiro, Editora Forense Universitária.

_. (1999), “O Legislativo como Arena de Interesses Organizados: A Atuação dos Lobbies Empresariais". Locus: Revista de História, vol. 5, nํ1, Juiz de Fora, Núcleo de História Regional/Departamento de História / Arquivo Histórico/EDUFJF.

. (2000), “Globalização, Herança Corporativa e a Representação dos Interesses Empresariais: Novas Configurações no Cenário Pós-Reformas", in R. Boschi (org.), Elites Políticas e Econômicas no Brasil Contemporâneo: A Desconstrução da Ordem Corporativa e o Papel do Legislativo no Cenário Pós-Reformas. São Paulo, Fundação Konrad Adenauer.

FIGUEIREDO, Argelina e LIMONGI, Fernando. (2000), “Presidential Power, Legislative Organization, and Party Behavior in Brazil". Comparative Politics, vol. 32, no 2. . (2001), Executivo e Legislativo na Nova Ordem Constitucional. São Paulo, Editora FGV /FAPESP.

HAGUENAUER, Lia, BAHIA, Luiz Dias, CASTRO, Paulo Furtado de e RIBEIRO, Márcio Bruno. (2001), "Evolução das Cadeias Produtivas Brasileiras na Década de 90". Texto para Discussão, nº 786, Brasília, IPEA.

HAY, Donald. (1997), “The Post 1990 Brazilian Trade Liberalization and the Performance of Large Manufacturing Firms: Productivity, Market Share and Profits". Texto para Discussão, no 523, Brasília, IPEA.

IEDI - Instituto de Estudos para o Desenvolvimento Industrial. (2000), Indústria e Desenvolvimento: Uma Análise dos Anos 90 e uma Agenda de Política de Desenvolvimento Industrial para a Nova Década. São Paulo, IEDI.

_.(2002), As Importações no Período 1995/2002. São Paulo, IEDI.

KING, Gary, KEOHANE, Robert e VERBA, Sidney. (1994), Designing Social Inquiry. New Jersey, Princeton University Press.

KINGSTONE, Peter. (2001), Re-inventing Business: Commercial Liberalization and the Response of Industrialists in Brazil. Trabalho apresentado na conferência Reforming Brazil, realizada no Bildner Center for Western Hemisphere Studies, City College of New York. 
LEOPOLDI, Maria Antonieta P. (2000), Política e Interesses na Industrialização Brasileira: As Associações Industriais, a Política Econômica e o Estado. São Paulo, Paz e Terra.

LYRA, Flávio Tavares de. (1996), “A Política Industrial Brasileira: Mudanças e Perspectivas". Texto para Discussão, no 413, Brasília, IPEA.

MANCUSO, Wagner Pralon. (2003), “Construindo Leis: As Construtoras e as Concessões de Serviços". Lua Nova, noำ 58 .

MIRANDA, José Carlos. (2001), “Abertura Comercial, Reestruturação Industrial e Exportações Brasileiras na Década de 1990". Texto para Discussão, no 829, Brasília, IPEA.

MOREIRA, Maurício Mesquita. (1999), “A Indústria Brasileira nos Anos 90. O Que Já se Pode Dizer?", in F. Giambiagi e M. M. Moreira (orgs.), A Economia Brasileira nos Anos 90. Rio de Janeiro, BNDES.

_ e CORREA, Paulo Guilherme. (1997), “Abertura Comercial e Indústria: O Que se Pode Esperar e o Que se Vem Obtendo". Revista de Economia Política, vol. 17, nº 2 .

OLSON, Mancur. (1982), The Rise and Decline of Nations. New Haven, Yale University Press.

PINHEIRO, Armando Castelar, GIAMBIAGI, Fábio e GOSTKORZEWICZ, Joana. (1999), “O Desempenho Macroeconômico do Brasil nos Anos 90”, in F. Giambiagi e M. M. Moreira (orgs.), A Economia Brasileira nos Anos 90. Rio de Janeiro, BNDES.

POWER, Timothy J. e DOCTOR, Mahrukh. (2002), The Resilience of Corporatism: Continuity and Change in Brazilian Corporatist Structures. Documento de Trabalho, Centro de Estudos Brasileiros, Universidade de Oxford.

ROSSI JÚNIOR, José Luiz e FERREIRA, Pedro Cavalcanti. (1999), “Evolução da Produtividade Industrial Brasileira e Abertura Comercial". Texto para Discussão, no 651, Brasília, IPEA.

SABÓIA, João e CARVALHO, Paulo Gonzaga M. de. (1997), "Produtividade na Indústria Brasileira - Questões Metodológicas e Análise Empírica". Texto para Discussão, no 504, Brasília, IPEA.

SCHNEIDER, Ben Ross. (1997a), Big Business and Constitutional Reform in Brazil. Trabalho apresentado na conferência Estrutura de Poder, Intermediação de Interesses e Elaboração de Políticas: Perspectivas para a Reforma do Estado no Brasil, Instituto de Estudos Latino-Americanos, Universidade de Londres.

. (1997b), "Big Business and the Politics of Economic Reform: Confidence and Concertation in Brazil and Mexico", in B. R. Schneider e S. Maxfield (eds.), Business and the State in Developing Countries. Ithaca, Cornell University Press.

. (1998), The State and Collective Action: Business Politics in Latin America. Trabalho apresentado no encontro da Latin American Studies Association realizado em Chicago.

. (2002), Some Consequences of Business Organization for Development and Democracy in Latin America. Trabalho apresentado no workshop Changing Nature of Business-State Relations in Brazil: Strategies of Foreign and Domestic Capital, St. Anthony's College. 
SIQUEIRA, Tagore Villarim de. (2000), “A Indústria Brasileira nos Últimos 16 Anos do Século XX: 1985/2000". Revista do BNDES, vol. 7, no 14.

SUZIGAN, Wilson e VILLELA, Annibal V. (1996), “Elementos para Discussão de uma Política Industrial para o Brasil". Texto para Discussão, no 421, Brasília, IPEA. . (1997), Industrial Policy in Brazil. Campinas, Instituto de Economia da Unicamp.

TULLOCK, Gordon. (1993), Rent-Seeking. London, Edward Elgar Publishing Limited.

VIANNA, Maria Lúcia T. W. (1994), “Lobismo: Um Novo Conceito para Analisar a Articulação de Interesses no Brasil”. Texto para Discussão, nº 25, Rio de Janeiro, Centro de Estudos de Políticas Públicas.

. (1998), A Americanização (Perversa) da Seguridade Social no Brasil: Estratégias de Bem-Estar e Políticas Públicas. Rio de Janeiro, IUPERJ-UCAM/Editora Revan.

WEYLAND, Kurt. (1998a), "The Fragmentation of the Business in Brazil”, in F. Durand e E. Silva (eds.), Organized Business, Economic Change, and Democracy in Latin America. Miami, North-South Center Press.

__.(1998b), "From Leviathan to Gulliver? The Decline of Developmental State in Brazil". Governance: An International Journal of Policy and Administration, vol. 11, no 1 .

. (2001), Brazilian Business and Market Reform: A Mixed Record. Trabalho apresentado no workshop The Brazilian Automotive Industry: Foreign Direct Investment and Business-State Relations, St. Anthony's College.

\section{ABSTRACT \\ The Industrial Lobby in Congress: Business Leaders and Politics in Contemporary Brazil}

The article shows how reducing external factors affecting competitivity, known as "custo Brasil" (which may include the cost of hiring labor, taxes on exports or the poor state of transportation infrastructure), has become the center of industry's political agenda. There follows a discussion of the current political situation of industrialists and their representatives in the process of producing federal legislation related to this cost. Thirdly, it proposed a method of measuring the degree of success achieved by industry. The method is to make a systematic comparison of the positions of industry to the decisions taken on bills listed in the Agendas Legislativas da Indústria, an annual publication of the National Confederation of Industry (CNI), prepared by a network of business organizations that includes, besides CNI, federations of industry and dozens of sectoral associations. In the fourth place, the article presents the findings obtained using the method. These 
finding indicate that industrialists are much more successful than might be expected by those who speak of a weak Brazilian industrial policy.

Key words: lobby, business leaders, industry, custo Brasil, executive branch, legislative branch

\section{RÉSUMÉ}

Le Lobby de l'industrie au Congrès Brésilien: Patronat et Politique dans le Brésil Contemporain

Dans cet article, on voit: 1) comment la réduction du "coût Brésil" est devenue le leit-motiv du calendrier politique du patronat de l'industrie; 2) l'action politique de ces industriels et de leurs représentants au long de la production des lois fédérales concernant le "coût Brésil"; 3) la méthode proposée dans le but de mesurer le degré de succès atteint par l'industrie méthode qui consiste dans la comparaison systématique entre la situation du secteur face au résultat des processus décisionnels concernant les projets des lois qui figurent dans les Agendas Legislativas da Indústria, une publication diffusée tous les ans par la Confédération Nationale de l'Industrie (CNI) et préparée par un réseau d'organisations d'entreprises comprenant, outre la CNI, les fédérations de l'industrie et quelques dizaines d'associations sectorielles; 4) les résultats obtenus par la mise en place de cette méthode. Ces résultats indiquent que le patronat de l'industrie y réussit bien mieux que ce que supposent les défenseurs de la thèse de la fragilité politique de l'industrie au Brésil.

Mots-clé: lobby; entreprises; industrie; "coût Brésil"; pouvoir exécutif; pouvoir législatif 